NBER WORKING PAPER SERIES

\title{
RETURN PREDICTABILITY IN THE TREASURY MARKET: REAL RATES, INFLATION, AND LIQUIDITY
}

\author{
Carolin E. Pflueger \\ Luis M. Viceira \\ Working Paper 16892 \\ http://www.nber.org/papers/w16892
NATIONAL BUREAU OF ECONOMIC RESEARCH
1050 Massachusetts Avenue
Cambridge, MA 02138
March 2011

We thank Tom Powers and Haibo Jiang for excellent research assistance. We are grateful to John Campbell, Kent Daniel, Graig Fantuzzi, Peter Feldhutter, Michael Fleming, Josh Gottlieb, Robin Greenwood, Arvind Krishnamurthy, George Pennacchi, Michael Pond, Matthew Richardson, Josephine Smith, Jeremy Stein, to seminar participants at the NBER Summer Institute 2011, the Econometric Society Winter Meeting 2011, the Federal Reserve Board, the European Central Bank, the New York Federal Reserve, the Foster School of Business at the U. of Washington, the HBS-Harvard Economics Finance Lunch and the HBS Finance Research Day for helpful comments and suggestions. We are also grateful to Martin Duffell and Anna Christie from the U.K. Debt Management Office for their help providing us with U.K. bond data. This material is based upon work supported by the Harvard Business School Research Funding. This paper was previously circulated under the title "An Empirical Decomposition of Risk and Liquidity in Nominal and Inflation-Indexed Government Bonds". The views expressed herein are those of the authors and do not necessarily reflect the views of the National Bureau of Economic Research.

NBER working papers are circulated for discussion and comment purposes. They have not been peerreviewed or been subject to the review by the NBER Board of Directors that accompanies official NBER publications.

(C) 2011 by Carolin E. Pflueger and Luis M. Viceira. All rights reserved. Short sections of text, not to exceed two paragraphs, may be quoted without explicit permission provided that full credit, including (C) notice, is given to the source. 
Return Predictability in the Treasury Market: Real Rates, Inflation, and Liquidity

Carolin E. Pflueger and Luis M. Viceira

NBER Working Paper No. 16892

March 2011, Revised October 2013

JEL No. G12

\begin{abstract}
Estimating the liquidity differential between inflation-indexed and nominal bond yields, we separately test for time-varying real rate risk premia, inflation risk premia, and liquidity premia in U.S. and U.K. bond markets. We find strong, model independent evidence that real rate risk premia and inflation risk premia contribute to nominal bond excess return predictability to quantitatively similar degrees. The estimated liquidity premium between U.S. inflation-indexed and nominal yields is systematic, ranges from 30 bps in 2005 to over 150 bps during 2008-2009, and contributes to return predictability in inflation-indexed bonds. We find no evidence that bond supply shocks generate return predictability.
\end{abstract}

\author{
Carolin E. Pflueger \\ Sauder School of Business \\ University of British Columbia \\ 2053 Main Mall \\ Vancouver, BC, V6T 1 Z2 \\ Canada \\ carolin.pflueger@sauder.ubc.ca \\ Luis M. Viceira \\ George E. Bates Professor \\ Harvard Business School \\ Baker Library 367 \\ Boston, MA 02163 \\ and NBER \\ lviceira@hbs.edu
}


There is wide consensus among financial economists that returns on nominal U.S. Treasury bonds in excess of Treasury bills are predictable at different investment horizons. Predictor variables include forward rates (Fama and Bliss, 1987), the slope of the yield curve (Campbell and Shiller, 1991), and a linear combination of forward rates (Cochrane and Piazzesi, 2005).

There is however an ongoing discussion about what drives this predictability. We contribute to this discussion by conducting a joint empirical analysis of the sources of excess bond return predictability in nominal and inflation-indexed bonds in the U.S. and the U.K. Specifically, we provide evidence that both time-varying inflation risk premia and time-varying real interest rate risk premia are quantitatively important in explaining time variation in the expected excess return on nominal bonds.

The question whether expected excess returns of inflation-indexed bonds are time-varying is important on its own. It remains relatively unexplored, partly due to the short history of U.S. inflation-indexed bonds (Campbell, Shiller, and Viceira, 2009). We contribute to the emerging research on inflation-indexed bonds by examining and distinguishing among three potential sources of excess return predictability in inflation-indexed bonds: time-varying real interest rate risk, timevarying liquidity risk, and market segmentation. Our work differs from recent work on inflationindexed bond return predictability by Campbell, Sunderam, and Viceira (2013) and Pflueger and Viceira (2011) in that it finds and corrects for an economically significant liquidity risk premium, which otherwise would likely distort estimates of real rate and inflation risk premia.

Novel and unique to our work is the finding that a liquidity component in breakeven inflation, or the spread between nominal and inflation-indexed bond yields of similar maturity, predicts the return differential between nominal and inflation-indexed bonds due to liquidity. The estimated U.S. return differential due to liquidity exhibits a significantly positive stock market CAPM beta, suggesting that U.S. TIPS investors bear systematic liquidity risk and should be compensated in terms of a positive return premium. While the return differential due to liquidity is not directly 
tradable, this result is relevant to investors who may differ in terms of their exposure to liquidity crises.

Research in financial economics has proposed several theories to explain predictability in nominal excess bond returns. One hypothesis is that excess return predictability results from time variation in the aggregate price of risk. Building on the habit preferences model of Campbell and Cochrane (1999), Wachter (2006) shows that a model with time-varying real interest rates can generate nominal bond excess return predictability.

Second, excess return predictability could result from time variation in expected aggregate consumption growth or its volatility. The long-run consumption risk model of Bansal and Yaron (2004) and Bansal, Kiku, and Yaron (2010) emphasizes this possibility. Bansal and Shaliastovich (2013) show that this, combined with time-varying inflation volatility, can explain nominal bond predictability.

If excess bond return predictability is entirely due to time-varying habit or long-run consumption risk, then excess returns of real bonds should be predictable, since prices of both real and nominal government bonds change with the economy-wide real interest rate. Prices of nominal, but not real, government bonds also vary with expected inflation, so excess returns on nominal bonds over real bonds should not be predictable.

A third hypothesis is that the nominal nature of bonds is an important source of time-varying risk premia. In this case, the wedge between nominal and real bond returns should be predictable. Time-varying inflation risk premia are an important source of bond risks in Buraschi and Jiltsov (2005), Piazzesi and Schneider (2007), Gabaix (2012), Bansal and Shaliastovich (2013), and Campbell, Sunderam, and Viceira (2013).

We use an empirically flexible approach to estimate the liquidity differential between inflationindexed and nominal bond yields. We regress breakeven onto bond market liquidity proxies while 
controlling for inflation expectation proxies. Liquidity proxies explain almost as much variation in U.S. breakeven as do inflation expectation proxies. We estimate that the sample average ten year U.S. TIPS yield would have been 69 basis points (bps) lower if TIPS had been as liquid as nominal Treasury bonds. Liquidity variables have smaller, but still significant, explanatory power for U.K. breakeven. We find no evidence that residuals from liquidity regressions are non-stationary, alleviating concerns that results might be spurious. Moreover, U.S. liquidity estimation results are robust to using quarterly changes instead of levels.

Conditional on estimates of liquidity-adjusted returns, we find strong evidence that returns on nominal bonds in excess of real bonds are predictable from the breakeven term spread. We find that real bond excess returns are predictable from the real term spread. Time-varying liquidity risk contributes statistically and economically significantly to predictability in inflation-indexed bond excess returns. Our results suggest that a well specified model of bond return predictability should match substantial predictability in liquidity-adjusted real bond excess returns and in the liquidity-adjusted differential between nominal and real bond excess returns.

Interpreting expected real bond excess returns as real rate risk premia and expected returns on nominal bonds in excess of real bonds as inflation risk premia, we find that both are similarly variable and strongly correlated with the nominal term spread. Therefore, both inflation and real rate risk appear quantitatively important in explaining the predictability of nominal bond excess returns documented by Campbell and Shiller (1991). Moreover, we find that real rate risk premia and inflation risk premia can contribute either positively or negatively to expected nominal bond excess returns. These empirical findings are consistent across the U.S. and the U.K.

Finally, we use the approach of Greenwood and Vayanos (2008) and Hamilton and Wu (2012) to test for segmentation between inflation-indexed and nominal bond markets as a non-fundamental source of bond excess return predictability. Recent research has emphasized the role of limited arbitrage and bond investors' habitat preferences to explain predictability in nominal bond re- 
turns (Modigliani and Sutch, 1966, Vayanos and Vila, 2009), but we find no evidence for similar segmentation between inflation-indexed and nominal bond markets.

Our work relates to a large literature that uses nominal term structure models to decompose nominal bond yields into expected inflation, expected real rates, inflation risk premia, and potentially liquidity. Recent studies include Ang, Bekaert and Wei (2008), D'Amico, Kim, and Wei (2008), Chen, Liu, and Cheng (2010), Christensen, Lopez, and Rudebusch (2010), Haubrich, Pennacchi and Ritchken (2012), and Campbell, Sunderam, and Viceira (2013). Our findings differ from these studies, which either do not study return-predictability or find inconclusive evidence (Haubrich, Pennacchi, and Ritchken, 2012). Moreover, our decomposition of nominal bond risk premia does not rely on a specific parameterization of the stochastic discount factor and it can therefore provide guidance for a much wider range of asset pricing models. Our approach allows us to use a well-developed array of tools to address identification concerns in the presence of persistent variables, which can plague both ordinary least squares and affine term structure models (Bauer, Rudebusch, and $\mathrm{Wu}, 2012)$.

Our work also builds on recent work by D'Amico, Kim, and Wei (2008) and Gurkaynak, Sack, and Wright (2010) estimating a liquidity discount in U.S. TIPS relative to U.S. Treasury bonds of similar maturity. Fleckenstein, Longstaff, and Lustig (2013) show evidence of price discrepancies between U.S. inflation swap and TIPS markets. In contrast to us, these studies do not study bond return predictability. ${ }^{2}$ We are not aware of any prior estimates of liquidity differentials between U.K. inflation-indexed and nominal bond markets.

Previous studies have tested for predictability in inflation-indexed bond excess returns (Barr and Campbell (1997), Evans (1998), Pflueger and Viceira (2011), Huang and Shi (2012)), but do not adjust for substantial liquidity components. Fontaine and Garcia (2012) argue that liquidity

\footnotetext{
${ }^{2}$ For additional evidence of relatively lower liquidity in U.S. TIPS, see Campbell, Shiller, and Viceira (2009), Fleming and Krishnan (2009), Dudley, Roush, and Steinberg Ezer (2009), Gurkaynak, Sack, and Wright (2010), Christensen and Gillan (2011).
} 
predicts excess returns on nominal bonds, but provide no evidence on inflation-indexed bonds.

\section{Bond Data and Definitions}

\section{A Bond Notation and Definitions}

Let $y_{n, t}^{\$}$ and $y_{n, t}^{T I P S}$ denote nominal and inflation-indexed log (or continuously compounded) yields with maturity $n$. We use the superscript TIPS for both U.S. and U.K. inflation-indexed bonds. Breakeven inflation is the difference between nominal and inflation-indexed bond yields:

$$
b_{n, t}=y_{n, t}^{\$}-y_{n, t}^{T I P S}
$$

Log excess returns on nominal and inflation-indexed zero-coupon $n$-period bonds held for one period before maturity are given by:

$$
\begin{aligned}
x r_{n, t+1}^{\$} & =n y_{n, t}^{\$}-(n-1) y_{n-1, t+1}^{\$}-y_{1, t}^{\$}, \\
x r_{n, t+1}^{T I P S} & =n y_{n, t}^{T I P S}-(n-1) y_{n-1, t+1}^{T I P S}-y_{1, t}^{T I P S} .
\end{aligned}
$$

Inflation-indexed bonds are commonly quoted in terms of real yields, but since $x r_{n, t+1}^{T I P S}$ is an excess return over the real short rate it can be interpreted as a real or nominal excess return. We approximate $y_{n-1, t+1}^{\$}$ and $y_{n-1, t+1}^{T I P S}$ with $y_{n, t+1}^{\$}$ and $y_{n, t+1}^{T I P S}$.

We define the log excess one-period breakeven return as the log return on a portfolio long one nominal bond and short one inflation-indexed bond with maturity $n$. This portfolio will have positive returns when breakeven inflation declines:

$$
x r_{n, t+1}^{b}=x r_{n, t+1}^{\$}-x r_{n, t+1}^{T I P S}
$$


The yield spread is the difference between a long-term yield and a short-term yield:

$$
\begin{aligned}
s_{n, t}^{\$} & =y_{n, t}^{\$}-y_{1, t}^{\$}, \\
s_{n, t}^{T I P S} & =y_{n, t}^{T I P S}-y_{1, t}^{T I P S}, \\
s_{n, t}^{b} & =b_{n, t}-b_{1, t} .
\end{aligned}
$$

\section{B Yield Data}

U.S. yields are from the zero-coupon off-the-run smoothed yield curves by Gurkaynak, Sack, and Wright (2007) and Gurkaynak, Sack, and Wright (2010, GSW henceforth). Using yields derived from a smoothed yield curve is likely to reduce non-fundamental fluctuations in yields and therefore to bias downward the volatility of the estimated liquidity premium. We focus on 10-year nominal and real yields, because this maturity has the longest sample period. Our sample period is 1999.32010.12 for yields and 1999.6-2010.12 for quarterly excess returns. We measure U.S. inflation with the all-urban seasonally adjusted CPI. The U.S. 3-month nominal interest rate is from the FamaBliss riskless interest rate file available on CRSP.

We use U.K. constant-maturity zero-coupon yield curves from the Bank of England, which are estimated with spline-based techniques (Anderson and Sleath, 2001). We use 20-year yields because those have the longest history. ${ }^{3}$ Our sample covers 1999.11-2010.12 for U.K. yields and 2000.2-2010.12 for U.K. quarterly excess returns because liquidity variables only become available at the end of 1999. We use the non seasonally adjusted Retail Price Index, which is also used to calculate inflation-indexed bond payouts. U.K. three month Treasury bill rates are from the Bank of England (IUMAJNB).

The nominal principal value of U.S. TIPS adjusts with the CPI, but it can never fall below

\footnotetext{
${ }^{3}$ For some months the 20 year yields are not available and instead we use the longest maturity available. The maturity used for the 20 year yield series drops down to 16.5 years for a short period in 1991 .
} 
its original nominal face value. Consequently, a recently issued TIPS, whose nominal face value is close to its original nominal face value, contains a potentially valuable deflation option (Wright (2010), Grishchenko, Vanden, and Zhang (2011)). We verify in Appendix Figure A.1 that the 10 year TIPS yield used for our empirical analysis corresponds closely to TIPS issuances with a high nominal face value. Our empirical measure of 10 year TIPS yield therefore likely does not contain a significant deflation option. U.K. inflation-indexed bonds do not contain a deflation option. ${ }^{4}$

Since neither the U.S. nor the U.K. governments issue inflation-indexed bills, we build a hypothetical short-term real interest rate following Campbell and Shiller (1996) as the predicted real return on the nominal three month T-bill. ${ }^{5}$ We use this real rate to construct excess returns on inflation-indexed bonds. Our results hold if we use instead nominal returns on inflation-indexed bonds in excess of the return on nominal T-bills. Finally, although our yield data is available monthly, we focus on quarterly overlapping bond returns to reduce the influence of high-frequency noise in observed inflation and short-term nominal interest rate volatility in our tests.

\section{Estimating the Liquidity Differential Between Inflation-Indexed and Nominal Bond Yields}

Breakeven inflation should reflect investors' inflation expectations plus any compensation for bearing inflation risk. However, if the inflation-indexed bond market is not as liquid as the nominal bond market, inflation-indexed bond prices might reflect a liquidity discount relative to nominal bonds,

\footnotetext{
${ }^{4}$ There are further details such as in inflation lags in principal updating and tax treatment of the coupons that slightly complicate the pricing of these bonds. More details on TIPS can be found in Viceira (2001), Roll (2004), Campbell, Shiller, and Viceira (2009) and Gurkaynak, Sack, and Wright (2010). Campbell and Shiller (1996) offer a discussion of the taxation of inflation-indexed bonds.

${ }^{5}$ We predict the real return on a nominal T-bill using the lagged real return on the nominal three month T-bill, the lagged nominal T-bill, and lagged four quarter inflation in Appendix Table A.I. For simplicity we assume a zero liquidity premium on one-quarter real bonds. Figure A.3 in the Appendix shows that the hypothetical U.S. real short-term rate corresponds very closely to an alternative proxy of the real short-term rate: the difference between the nominal short-term rate minus the Survey of Professional Forecasters median one quarter CPI inflation forecast.
} 
or equivalently a liquidity premium in yields. This liquidity differential will impact breakeven inflation negatively.

We pursue an empirical approach to identify the liquidity differential between inflation-indexed and nominal bond markets in the U.S. and the U.K. We estimate the liquidity differential by regressing breakeven inflation on measures of liquidity as in D'Amico, Kim, and Wei (2008) and Gurkaynak, Sack, and Wright (2010), while controlling for inflation expectation proxies. We capture different notions of liquidity through three different liquidity proxies: the nominal off-the-run spread, relative transaction volume of inflation-indexed bonds and nominal bonds, and proxies for the cost of funding a levered investment in inflation-indexed bonds.

Time-varying market-wide desire to hold only the most liquid securities, such as "flight to liquidity" episodes, might drive part of the liquidity differential between nominal and inflation-indexed bonds. We capture this notion of liquidity by the nominal U.S. off-the-run spread. The Treasury regularly issues new 10 year nominal notes and the newest "on-the-run" note is considered the most liquidly traded security in the Treasury bond market. The older "off-the-run" bond typically trades at a discount - i.e., at a higher yield - despite offering almost identical cash flows (Krishnamurthy, 2002). ${ }^{6}$ The U.K. Treasury market does not have on-the-run and off-the-run bonds in a strict sense, since the Treasury typically reopens existing bonds to issue additional debt. We capture liquidity in the U.K. nominal government bond market with the difference between a fitted par yield and the yield on the most recently issued 10 year nominal bond, similarly to $\mathrm{Hu}$, Pan, and Wang (2013). Hu, Pan, and Wang (2013) argue that such a measure captures market-wide liquidity and the availability of arbitrage capital. We refer to this U.K. measure as the "off-the-run spread" for simplicity.

Liquidity developments specific to inflation-indexed bond markets might also generate liquidity

\footnotetext{
${ }^{6}$ In the search model with partially segmented markets of Vayanos and Wang (2007) short-horizon traders endogenously concentrate in one asset, making it more liquid. Vayanos (2004) presents a model of financial intermediaries and exogenous transaction costs, where preference for liquidity is time-varying and increasing with volatility.
} 
premia. When U.S. TIPS were first issued in 1997, investors might have had to learn about them and the TIPS market might have taken time to get established. More generally, following Duffie, Garleanu and Pedersen $(2005,2007)$ and Weill (2008), one can think of the transaction volume of inflation-indexed bonds as a measure of illiquidity due to search frictions. ${ }^{7}$ We proxy for this idea with the transaction volume of inflation-indexed bonds relative to nominal bonds for the U.S. and the U.K., a measure previously used by Gurkaynak, Sack, and Wright (2010) for U.S. TIPS. Fleming and Krishnan (2009) also provide evidence that trading activity is a good measure of cross-sectional TIPS liquidity.

Finally, we want to capture the cost of arbitraging between inflation-indexed and nominal bond markets for levered investors, and more generally the availability of arbitrage capital and the shadow cost of capital (Garleanu and Pedersen, 2011). In the U.S. and the U.K., levered investors looking for inflation-indexed bond exposure can borrow by putting the bond on repo. In the U.S., investors can alternatively enter an asset swap. We use the difference between the asset-swap spreads for U.S. TIPS and nominal Treasuries to proxy for current and expected relative financing costs:

$$
A S W_{n, t}^{\text {spread }}=A S W_{n, t}^{T I P S}-A S W_{n, t}^{\$} .
$$

An asset-swap is a derivative contract, where one party receives the cash flows on a particular government bond (TIPS or nominal) and pays LIBOR plus the asset-swap spread $(A S W)$, which can be positive or negative. A non-levered investor who perceives TIPS to be under priced relative to nominal Treasuries can enter a zero price portfolio long one dollar of TIPS and short one dollar of nominal Treasuries. A levered investor can similarly enter a position long one TIPS asset-swap and short one nominal Treasury asset-swap. This levered investor pays the relative spread (8), which is typically positive, for the privilege of not having to put up any initial capital.

\footnotetext{
${ }^{7}$ See Duffie, Garleanu, and Pedersen (2005, 2007) and Weill (2008) for models of over-the-counter markets, in which traders need to search for counter parties and incur opportunity or other costs while doing so.
} 
The asset-swap spread and the off-the-run spread are likely related to specialness of nominal Treasuries in the repo market and the lack of specialness of TIPS, which can vary over time. ${ }^{8}$ Differences in specialness might be the result of variation in the relative liquidity of securities, which make some securities easier to liquidate and hence more attractive to hold than others.

For robustness, we consider the spread between synthetic breakeven and cash breakeven. A zerocoupon inflation swap is a contract, where at maturity one party pays cumulative CPI inflation in exchange for a pre-determined fixed rate. The fixed rate is often referred to as synthetic inflation. A zero coupon inflation swap does not require any initial capital, similarly to entering an asset swap. The difference between synthetic breakeven and cash breakeven is therefore the flip side of the asset-swap spread (Viceira, 2011).

Fleckenstein, Longstaff, and Lustig (2013) show evidence of price discrepancies between U.S. inflation swap and TIPS markets. When TIPS and inflation derivatives are not traded by the same marginal investor and investors face borrowing constraints, derivatives may not reflect all non-fundamental related fluctuations in TIPS prices. Moreover, inflation derivatives data is only available over a significantly shorter U.S. sample. We therefore control for investors' ability to finance a levered bond position, as reflected by mispricing between derivatives and bond markets, as an important but not the only potential source of non-payoff related fluctuations. We use the asset-swap spread as our benchmark variable, since it most closely captures the relative financing cost and specialness of TIPS over nominal Treasuries.

U.K. asset-swap spread or inflation swap data is not available. We use the LIBOR-general collateral (GC) repo interest-rate spread, as suggested by Garleanu and Pedersen (2011), to proxy for arbitrageurs' shadow cost of capital. In contrast to the asset-swap spread, this measure cannot

\footnotetext{
${ }^{8}$ Holders of certain bonds may be able to borrow at 'special' collateralized loan rates below general market interest rates (Duffie, 1996, Buraschi and Menini, 2002). In private email conversations Michael Fleming and Neel Krishnan report that for the period Feb. 4, 2004 to the end of 2010 average repo specialness was as follows. On-the-run coupon securities: 35 bps; off-the-run coupon securities: 6 bps; T-Bills: 13 bps; TIPS: 0 bps.
} 
capture time-varying margin requirements of inflation-indexed bonds relative to nominal bonds.

The estimated liquidity premium likely represents a combination of current ease of trading and the risk that liquidity might deteriorate: If the liquidity of inflation-indexed bonds deteriorates during periods when investors would like to sell, as in "flight to liquidity" episodes, risk averse investors will demand a liquidity risk premium (Amihud, Mendelson, and Pedersen, 2005, Acharya and Pedersen, 2005). While the relative transaction volume of inflation-indexed bonds likely only captures the current ease of trading, the off-the-run spread, the smoothness of the nominal yield curve, the asset-swap spread and the LIBOR-GC spread are likely to represent both current liquidity and liquidity risk.

\section{A Estimation Strategy}

Let $b_{n, t}$ be breakeven inflation, $X_{t}$ a vector of liquidity proxies, and $\pi_{t}^{e}$ a vector of inflation expectation proxies. We estimate:

$$
b_{n, t}=a_{1}+a_{2} X_{t}+a_{3} \pi_{t}^{e}+\varepsilon_{t},
$$

Let $\hat{a}_{2}$ denote the vector of slope estimates in (9). The estimated liquidity premium in inflationindexed yields over nominal yields is the negative of the variation in $b_{n, t}$ explained by the liquidity variables:

$$
\hat{L}_{n, t}=-\hat{a}_{2} X_{t}
$$

Variables indicating less liquidity in the inflation-indexed bond market, such as the off-the-run spread, the smoothness of the nominal yield curve, the asset-swap spread, and the LIBOR-GC spread, should enter negatively in (9). The relative transaction volume of the inflation-indexed bonds should enter positively. 
We normalize liquidity variables to equal zero in a world of perfect liquidity. With perfect liquidity, the off-the-run spread, the smoothness of the nominal yield curve, the asset-swap spread, and the LIBOR-GC spread should be zero. U.S. and U.K. relative transaction volumes are normalized to a maximum of zero. This assumption might bias the estimated liquidity differential downward and does not affect the liquidity differential's estimated variability.

In order to obtain consistent liquidity estimates, the regression residual $\varepsilon_{t}$ needs to be uncorrelated with liquidity proxies, controlling for inflation expectations. We do not include inflation risk proxies in the liquidity estimation (9) so as not to not preclude the outcome of our analysis. Not controlling for inflation risk premia is conservative in the following sense: If the estimated liquidity premium also happens to pick up on inflation risk premia in nominal bonds, then this should bias us against finding predictability in liquidity-adjusted breakeven returns.

If our liquidity proxies contain information on inflation expectations not already captured by included inflation variables, our estimate of the liquidity premium may be biased. We think that this is unlikely given that we control comprehensively for inflation expectations. In any case, changes in inflation expectations are not predictable if agents are rational. In that case, even if our estimate of the liquidity premium is correlated with inflation expectations, this type of potential mis-estimation will not introduce return predictability in either liquidity or liquidity-adjusted bond returns.

While our liquidity estimate most likely reflects liquidity fluctuations in both nominal bonds and in inflation-indexed bonds, we have to make an assumption in computing liquidity-adjusted inflation-indexed bond yields. We could assume that all of the liquidity premium is in nominal bonds, in which case we would not need to correct inflation-indexed bond yields. Alternatively, we could assume that the relative liquidity premium is entirely attributable to inflation-indexed bond illiquidity. To allow for comparison between these two possibilities, we calculate inflation-indexed bond yields under the second assumption. We refer to the following variables as liquidity-adjusted 
inflation-indexed bond yields and liquidity-adjusted breakeven:

$$
\begin{aligned}
y_{n, t}^{\text {TIPS }, a d j} & =y_{n, t}^{\text {TIPS }}-\hat{L}_{n, t}, \\
b_{n, t}^{a d j} & =b_{n, t}+\hat{L}_{n, t} .
\end{aligned}
$$

\section{B Data on Liquidity and Inflation Expectation Proxies}

The U.S. off-the-run spread is the difference between the 10 year GSW off-the-run par yield and the 10 year on-the-run nominal bond yield from Bloomberg (USGG10YR). ${ }^{9}$ For the U.K., we use the difference between the fitted 10 year nominal par yield available from the Bank of England (IUMMNPY) and the 10 year nominal on-the-run yield from Bloomberg.

We calculate U.S. and U.K. relative transaction volume as $\log \left(\operatorname{Trans}_{t}^{T I P S} / \operatorname{Trans}_{t}^{\$}\right)$ smoothed over the past three months. Here, $\operatorname{Trans}_{t}^{\text {TIPS }}$ and $\operatorname{Trans}_{t}^{\$}$ denote average monthly transaction volume for inflation-indexed and long-term nominal bonds. We use transaction volume for longterm nominal coupon bonds to capture the liquidity differential between inflation-indexed and equivalent maturity nominal bonds. ${ }^{10}$

[FIGURE 1 ABOUT HERE]

Data on $A S W_{n, t}^{\text {spread }}$ is from Barclays Live from January 2004 and we set it to its January 2004 value of 28 bps before that date. 10 year zero-coupon inflation swaps are available from Bloomberg

\footnotetext{
${ }^{9}$ Alternatively, we can discount the on-the-run bond cash flows at the Gurkaynak, Sack, and Wright (2007) offthe-run yield curve. The obtaining off-the-run spread is $85 \%$ correlated with our baseline measure. Appendix Table A.XV shows that liquidity estimates are robust to using the alternative off-the-run spread.

${ }^{10}$ For the U.S., we use Primary Dealers' transaction volumes from the New York Federal Reserve FR-2004 survey. We are grateful to Martin Duffell from the U.K. Debt Management Office for providing us with U.K. turnover data. In 2001 the Federal Reserve changed the maturity cutoffs. Before 6/28/2001 we use the transaction volume of Treasuries with 6 or more years to maturity while starting $6 / 28 / 2001$ we use the transaction volume of Treasuries with 7 or more years to maturity. The series after the break is scaled so that the growth in Trans ${ }^{\$}$ from 6/21/2001 to 6/28/2001 is equal to the growth in transaction volume of all government coupon securities.
} 
(USDSW10Y) from July 2004 onwards. The U.K. LIBOR-GC spread is the difference between three month British Pound LIBOR and three month British Pound GC rates from Bloomberg.

Figures $1 \mathrm{~A}$ and $1 \mathrm{~B}$ plot the time series of the U.S. and U.K. liquidity variables. The U.S. off-the-run spread was high during the late 1990s, declined during 2005-2007, and jumped to over 50 bps during the financial crisis. U.S. relative transaction volume rises linearly through 2004 and then stabilizes. The asset-swap spread $A S W_{n, t}^{\text {spread }}$ varies within a relatively narrow range of 21 to 41 bps between January 2004 and December 2006. Before the crisis, it was about 30 bps more expensive to finance a long position in TIPS than in nominal Treasury bonds. This cost differential rose sharply during the financial crisis, reaching 130 bps in December 2008. Campbell, Shiller, and Viceira (2009) argue that the Lehman bankruptcy significantly affected TIPS liquidity because Lehman Brothers had been very active in the TIPS market. The unwinding of its large TIPS inventory, combined with a sudden increase in the cost of financing long positions in TIPS appears to have induced unexpected downward price pressure in the TIPS market. The asset-swap spread $A S W_{n, t}^{\text {spread }}$ and the differential between synthetic and cash breakeven inflation track very closely, as expected.

Figure 1B shows a steady increase in the U.K. relative transaction volume until 2005. Greenwood and Vayanos (2010) argue that the U.K. pension reform of 2004, which required pension funds to discount future liabilities at long-term real rates, increased demand for inflation-indexed gilts and it seems plausible that the same reform also increased trading volume. Figure 1B shows that the LIBOR-GC spread peaked during the financial crisis, consistent with the notion that arbitrageurs' capital was scarce during this period. The smoother U.K. off-the-run spread might indicate that during flight-to-liquidity episodes investors have a preference for U.S. on-the-run nominal Treasuries.

We proxy for U.S. inflation expectations with the median 10 year CPI inflation forecast from the Survey of Professional Forecasters (SPF), consistent with bond maturities. We also include 
the Chicago Fed National Activity Index (CFNAI) to account for the possibility that shorter-term inflation expectations enter into breakeven (Stock and Watson, 1999). ${ }^{11}$ We proxy for U.K. inflation expectations using the median response to the question "How much would you expect prices in the shops generally to change over the next 12 months?' from the Bank of England Public Attitudes survey. Unfortunately, no longer forecasting horizon is available for our sample.

\section{[TABLE I ABOUT HERE]}

Summary statistics in Table I suggest that there was a substantial liquidity premium in U.S. TIPS yields relative to nominal yields, or a substantial negative inflation risk premium in nominal yields. Over our sample, U.S. average breakeven was $2.24 \%$ per annum (p.a.), average TIPS yields were $2.44 \%$ p.a., and average U.S. survey inflation was $2.47 \%$ p.a. If breakeven exclusively reflected investors' inflation expectations, the negative gap between U.S. breakeven and survey inflation would be surprising, especially given that the SPF tends to under predict inflation in low inflation environments (Ang, Bekaert, and Wei, 2007). In contrast, average U.K. breakeven exceeded survey inflation over the similar period 1999.11-2010.12.

Table I shows that realized log excess returns on U.S. TIPS averaged $4.66 \%$ p.a. and exceeded average log excess returns on U.S. nominal government bonds by 48 bps over our sample. Average log excess returns on U.K. inflation-indexed bonds were substantially smaller at only $2.36 \%$ p.a., but exceeded U.K. nominal log excess returns by $1.80 \%$ p.a.

\footnotetext{
${ }^{11}$ SPF survey expectations are available at a quarterly frequency and are released towards the end of the middle month of the quarter. We create a monthly series by using the most recently released inflation forecast.
} 


\section{Estimating Differential Liquidity}

Table IIA and IIB estimate the relation (9) for the U.S. and the U.K., respectively. We add liquidity proxies one at a time. For both panels, column (4) presents our benchmark estimate with all liquidity proxies and inflation expectation controls. The last two columns verify that results are robust to excluding the financial crisis.

\section{[TABLE II ABOUT HERE]}

Table IIA column (1) shows that inflation expectation proxies jointly explain $39 \%$ of the variability in U.S. breakeven. CFNAI enters positively and significantly, suggesting that short-run inflation expectations influence investors' long-run inflation expectations. Table I shows that SPF inflation expectations exhibit very little time variation. Table II suggests that this variation is unrelated to breakeven, after controlling for liquidity proxies and CFNAI.

Panel A shows that liquidity measures explain significant variation in U.S. breakeven inflation. The regression $R^{2}$ increases with the inclusion of every additional liquidity variable and reaches $66 \%$ in column (4). Column (2) shows that the off-the-run spread alone increases the regression $R^{2}$ by 21 percentage points. Appendix Table A.II shows that each variable alone also explains significant variation in breakeven inflation.

The coefficients in Table IIA are consistent with intuition and they are statistically significant. Breakeven inflation decreases in the off-the-run spread, suggesting that TIPS yields reflect a strong market-wide liquidity component. A one standard deviation move in the off-the-run spread of 11 bps tends to go along with a decrease in breakeven of 9.5 bps in our benchmark estimation $(0.87 \times 11$ bps). These magnitudes are substantial relative to average breakeven of 224 bps. This empirical finding indicates that during flight-to-liquidity episodes, investors prefer nominal on-the-run U.S. 
Treasuries over U.S. TIPS, even though both types of bonds are fully backed by the U.S. Treasury.

Relative TIPS trading volume enters positively and significantly, indicating that search frictions impacted inflation-indexed bond prices during the early period of inflation-indexed bond issuance. As TIPS trading volume relative to nominal Treasury trading volume increased, TIPS yields fell relative to nominal bond yields. Our empirical estimates suggest that an increase in relative trading volume from its minimum in 1999 to its maximum in 2004 was associated with a decrease in the TIPS liquidity premium of 48 bps.

When the marginal investor in TIPS is levered, we would expect breakeven to fall one for one with the asset-swap differential. The estimated slope on the asset-swap spread is at -0.86 well within one standard deviation of the theoretical value of -1 . This slope estimate suggests that disruptions to securities markets and constraints on levered investors were important in explaining the sharp fall in breakeven during the financial crisis, since the asset-swap spread differential behaves almost like a dummy variable that spikes up during the financial crisis. We obtain similar results estimating the regression for the synthetic minus cash breakeven spread.

We also find a strong relationship between breakeven and liquidity proxies during the pre-crisis period. Column (6) in Panel A shows that before 2007, proxies for inflation expectations explain $30 \%$ of the variability of breakeven inflation. Column (7) shows that adding liquidity proxies more than doubles the regression $R^{2}$ to $61 \%$ and that the off-the-run spread enters with a strongly negative and significant coefficient.

Since some liquidity variables are persistent, one might be concerned about spuriousness. If there is no slope vector so that the regression residuals are stationary, Ordinary Least Squares is quite likely to produce artificially large $R^{2} s$ and t-statistics (Granger and Newbold, 1974, Phillips, 1986, Hamilton, 1994). Table II shows that the augmented Dickey-Fuller test rejects the presence of a unit root in regression residuals for all regression specifications at conventional significance 
levels. Appendix Table A.III shows that the U.S. regression results in quarterly changes are very similar to those in levels, further alleviating concerns.

Our estimation of the liquidity premium might rely on extrapolation outside the range of historically observed liquidity events. Nonlinear effects might be especially important during events of extreme liquidity or extreme illiquidity. Appendix Tables A.IV reports additional results including interaction terms. Appendix Table A.IV also shows that the bid-ask spread does not enter, suggesting that the other liquidity proxies already incorporate the time-varying round-trip cost of buying and selling TIPS. $^{12}$

Appendix Table XV illustrates that our results are robust to using an alternative measure for the off-the-run spread. The alternative off-the-run spread compares 10 year nominal on-the-run bond yields with yields derived from discounting the on-the-run cash flows at the Gurkaynak, Sack and Wright (2007) off-the-run curve, as described in the Supplementary Appendix. Table XV also shows that Fontaine and Garcia (2012) bond market liquidity factor does not enter in addition to the other liquidity variables.

Table IIB shows that U.K. survey inflation explains $51 \%$ of the variability in U.K. breakeven. Liquidity proxies enter with the predicted signs and increase the regression $R^{2}$ substantially to $65 \%$. Interestingly, columns (5) and (6) show that prior to the financial crisis, liquidity variables have even greater explanatory power. In the pre-2007 sample, including the liquidity variables more than doubles the $R^{2}$ to $67 \%$. While in the full sample only relative transaction volume is individually statistically significant, in the pre-2007 sample the smoothness of the nominal yield curve also becomes statistically significant. Again, the augmented Dickey-Fuller tests reject the presence of a unit root for all regression specifications in the panel. Overall these results suggest that liquidity factors are important for understanding the time series variability of breakeven inflation both in the U.S. and the U.K.

\footnotetext{
${ }^{12}$ We are grateful to George Pennacchi for making his proprietary data on TIPS bid-ask spreads available to us.
} 


\section{[FIGURES 2A AND 2B ABOUT HERE]}

Figures 2A and 2B plot estimated U.S. and U.K. liquidity premia from Table IIA (4) and Table IIB (4). The estimated U.S. liquidity premium averages 69 bps with a standard deviation of 24 bps over our sample. This high average reflects periods of very low liquidity in this market. Figure 2A shows a high liquidity premium in the early 2000's (about 70-100 bps), but a much lower liquidity premium between 2004 and 2007 (35-70 bps). The premium shoots up again beyond 150 bps during the crisis, and finally comes down to 50 bps after the crisis.

The estimated U.S. liquidity time series is consistent with previous estimates (D'Amico, Kim, and Wei (2008), Dudley, Roush, and Steinberg Ezer (2009), Gurkaynak, Sack, Wright (2010), Christensen and Gillan (2011), Haubrich, Pennacchi, and Ritchken (2012), Fleckenstein, Longstaff, and Lustig (2013)). However, we consider a more comprehensive set of liquidity proxies and estimate U.S. liquidity over a longer time period. We are not aware of any previous estimates of the liquidity differential between U.K. inflation-indexed and nominal bond yields.

The large liquidity premium in TIPS is puzzling given narrow TIPS bid-ask spreads. Haubrich, Pennacchi, and Ritchken (2012) report TIPS bid-ask spreads of at most 10 bps during the financial crisis. It seems implausible that the liquidity premium in TIPS yields simply serves to amortize transaction costs of a long-term investor. ${ }^{13}$ If TIPS are held by buy-and-hold investors, as previously argued, then transaction costs of 10 bps can only justify a 1 bp liquidity premium for 10 year TIPS (Amihud, Mendelson, and Pedersen (2005)).

A simple calculation shows that the estimated liquidity premium in U.S. TIPS, though puzzlingly large when compared to bid-ask spreads, gives rise to liquidity returns in line with those on off-the-run nominal Treasuries. The on-the-run off-the-run liquidity differential converges in 6

\footnotetext{
${ }^{13}$ See also Wright (2009).
} 
months, when the new on-the-run nominal 10-year bond is issued. Thus, an average U.S. off-therun spread of 21 bps yields an annualized return on the liquidity differential of $21 \times 10 \times 2$ bps $=420$ bps. In contrast, the 10 year U.S. TIPS liquidity premium might take as long as 10 years to converge, yielding an average annualized return on U.S. TIPS liquidity of only 69 bps.

The estimated U.K. liquidity premium has a lower average (50 bps) but a similar standard deviation (24 bps) compared to U.S. liquidity. Figure 2B shows that the estimated U.K. liquidity premium was initially similar to the U.S. liquidity premium (around $100 \mathrm{bps)}$ and stabilized around 40 bps after 2005. It even became negative during the financial crisis, reflecting extremely high relative transaction volume in U.K. inflation-indexed bonds.

\section{[FIGURE 3 ABOUT HERE]}

Figure 3A shows that liquidity-adjusted U.S. breakeven was substantially more stable than raw U.S. breakeven. Estimated liquidity-adjusted U.S. breakeven averaged $2.93 \%$ with a standard deviation of 25 bps over our sample. Adjusting breakeven for liquidity suggests that while investors' U.S. long-term inflation expectations fell during the crisis, there was never a period when investors feared substantial long-term deflation in the U.S.

Figure 3B partly attributes the strong upward trend in U.K. breakeven inflation to liquidity. However, even after adjusting for liquidity U.K. breakeven has trended upwards from around $3 \%$ to $4 \%$ over our sample. In contrast to the U.S., U.K. breakeven does not exhibit a pronounced drop during the financial crisis. Both raw and liquidity-adjusted U.K. breakeven become highly volatile during 2008-2010, potentially reflecting inflation uncertainty. 


\section{Testing for Preferred Habitat in U.S. and U.K. Inflation-Indexed and Nominal Bond Markets}

Section II shows that liquidity, understood as market factors not directly related to real interest rate and inflation fundamentals, explains substantial variation in breakeven inflation or the yield differential between nominal bonds and inflation-indexed bonds in both the U.S. and U.K. bond markets. This section tests for another potential source of non-fundamental variation in bond valuations and returns: market segmentation due to preferred habitat preferences and limited arbitrage.

We consider a natural extension of the market segmentation hypothesis of Modigliani and Sutch (1966) and Vayanos and Vila (2009). Inflation-indexed and nominal bond markets might be segmented due to different investor clientles: Conservative long-term investors or pension funds with inflation-indexed liabilities might have a natural preference for inflation-indexed bonds, while pension funds with nominal liabilities or global investors seeking highly liquid, non-defaultable securities might have a natural preference for nominal bonds. If arbitrage capital is limited, we might observe temporary price divergences between the two markets that are unrelated to fundamentals.

Our empirical setup is similar to Greenwood and Vayanos (2008) and Hamilton and Wu (2012). If supply is subject to exogenous shocks while clientle demand is stable over time, relative supply of inflation-indexed bonds should be inversely related to breakeven, as the price of inflation-indexed bonds falls in response to excess supply. Subsequently we would expect to see positive returns on inflation-indexed bonds as their prices rebound.

Let $D_{t}^{T I P S}$ denote the face value of inflation-indexed bonds outstanding and $D_{t}$ the combined face value of nominal and inflation-indexed bonds outstanding for either the U.S. or the U.K. We 
define relative supply $S u p p l y_{t}$ and relative issuance $\Delta$ Supplyt $:^{14}$

$$
\begin{aligned}
\text { Supplyt }_{t} & =D_{t}^{T I P S} / D_{t} \\
\Delta \text { Supplyt }_{t} & =\left(D_{t}^{T I P S}-D_{t-1}^{T I P S}\right) / D_{t-1}^{T I P S}-\left(D_{t}-D_{t-1}\right) / D_{t-1} .
\end{aligned}
$$

We also construct a measure of unexpected relative issuance $\varepsilon_{t}^{\text {Supply }}$. Dickey-Fuller tests in Appendix Table A.XII show that we cannot reject a unit root in U.S. Supplyt or $\Delta$ Supplyt. However, the year-over-year change in U.S. relative issuance appears stationary and we construct $\varepsilon_{t}^{\text {Supply }}$ as the residual from an autoregression of $\Delta S$ Supplyt $-\Delta S$ Spplyt-12 with twelve lags. In the U.K. we reject stationarity in relative issuance $\Delta S$ upplyt, potentially reflecting the less regular U.K. bond issuance cycle. We therefore construct the U.K. supply shock $\varepsilon_{t}^{\text {Supply }}$ as the residual from an autoregression of $\Delta$ Supply $y_{t}$ with twelve lags.

\section{[FIGURE 4 ABOUT HERE]}

Figures $4 \mathrm{~A}$ and $4 \mathrm{~B}$ plot the relative supply of inflation-indexed bonds and breakeven in the U.S. and the U.K. Starting from less than $2 \%$ in 1997 TIPS increased to represent over $14 \%$ of the U.S. Treasury coupon bond portfolio in 2008. The relative share of U.K. linkers has increased from about $9 \%$ in 1985 to $16 \%$ in 2010 .

\section{[TABLE III ABOUT HERE]}

\footnotetext{
${ }^{14}$ We measure the relative supply of inflation-indexed bonds in the U.S. as the nominal amount of TIPS outstanding relative to U.S. government TIPS, notes and bonds outstanding. U.K. relative supply is the total amount of inflationlinked gilts relative to the total amount of conventional gilts outstanding. The economic report of the president reports U.S. Treasury securities by kind of obligation and reports T-bills, Treasury notes, Treasury bonds and TIPS. The data can be found in Table 85 until 2000 and in Table 87 afterwards at http://www.gpoaccess.gov/eop/download.html. The face value of TIPS outstanding available in the data is the original face value at issuance times the inflation incurred since then and therefore it increases with inflation. The numbers include both privately held Treasury securities and Federal Reserve and intra-governmental holdings as in Greenwood and Vayanos (2008). We are deeply grateful to the U.K. Debt Management Office for providing us with data. Conventional U.K. gilts exclude floatingrate and double-dated gilts but include undated gilts. The face value of U.K. index-linked gilts does not include inflation-uplift and is reported as the original nominal issuance value.
} 
Table III finds no relation between breakeven and relative supply measures $S u p p l y_{t}, \Delta S u p p l y_{t}$, $\epsilon_{t}^{\text {Supply }}$ while controlling for inflation expectations in the U.S. or the U.K. Table IIIA shows that U.S. relative supply enters with a positive and significant coefficient, but the coefficient becomes insignificant when controlling for liquidity proxies and a time trend. Neither relative issuance nor relative supply shocks $\varepsilon_{t}^{\text {Supply }}$ enter significantly, either individually or when controlling for liquidity variables and a time trend.

Table IIIB shows similar empirical results for the U.K. The U.K. results are consistent between a significantly longer sample and a shorter sample with liquidity controls. Relative supply enters positively and significantly, but becomes insignificant when including a time trend. The U.K. time trend is highly statistically significant and dramatically increases the regression $R^{2}$.

We can reconcile the findings in this section with Fleckenstein, Longstaff, and Lustig (2013), who argue that the supply of Treasury securities affects liquidity and hence the relative mispricing of inflation-indexed and nominal bonds. We use the theoretically motivated relative supply of inflation-indexed bonds, while they include both the supply of TIPS and of Treasuries separately. They find that TIPS become relatively more expensive when the Treasury issues more TIPS, which seems inconsistent with market segmentation and supply shocks driving breakeven and consistent with our results.

If markets are segmented in the sense of Greenwood and Vayanos (2008), an unexpected increase in the relative supply of inflation-indexed bonds should negatively predict breakeven returns. Table IV regresses nominal, inflation-indexed and breakeven returns onto lagged relative supply. We find no evidence that U.S. or U.K. supply variables predict bond excess returns. We include the nominal term spread as a well-known predictor of nominal bond excess returns (Campbell and Shiller (1991)) and the breakeven and inflation-indexed term spreads as predictors of breakeven and inflation-indexed bond excess returns (Pflueger and Viceira (2011)). We control for lagged relative 
inflation-indexed bonds liquidity to account for potentially time-varying liquidity risk premia.

\section{[TABLE IV ABOUT HERE]}

Table IV shows that relative supply shocks cannot explain the predictability of bond excess returns from term spreads. Even after controlling for supply effects, the nominal term spread forecasts nominal bond excess returns positively and it enters significantly for the U.K. long sample. The breakeven term spread predicts breakeven excess returns both in the U.S. and the U.K. The inflation-indexed bond term spread predicts inflation-indexed bond excess returns in the U.K. long sample and is marginally significant for the U.S. and the U.K. shorter samples.

In summary, there is no evidence of relative supply shocks predicting bond excess returns in either the U.S. or the U.K. A potential alternative hypothesis is that bond demand changes over time while the government accommodates demand, effectively acting as an arbitrageur between the two markets. In this case, relative supply of inflation-indexed bonds might be unrelated to subsequent returns, and possibly even positively correlated with contemporaneous breakeven inflation. ${ }^{15}$ Appendix Figures A.4 and A.5 explore the effect of supply shocks on breakeven in structural VARs in the U.S. and the U.K. These impulse responses are consistent with the U.S. and U.K. governments increasing relative issuance of inflation-indexed bonds when breakeven is high and inflation-indexed bonds are relatively expensive.

\footnotetext{
${ }^{15}$ Unlike the U.S. Treasury, the U.K. Debt Management Office has an irregular auction calendar and appears to take into account bond demand when deciding the size and characteristics of bond issues. The issuance of inflationindexed and nominal bonds is likely to be endogenous.
} 


\section{Bond Excess Return Predictability}

This section decomposes government bond excess returns into returns due to real interest rates, changing inflation expectations, and liquidity. We test for predictability in each component separately: Predictability in liquidity-adjusted real bond excess returns would indicate a time-varying real interest rate risk premium, while predictability in liquidity-adjusted breakeven returns would indicate a time-varying inflation risk premium. Predictability in the liquidity component of inflationindexed returns would indicate a time-varying liquidity risk premium. Having found no evidence that relative supply shocks and preferred habitat generate bond excess return predictability, we rule out this potential channel for the remaining analysis. ${ }^{16}$

We adjust inflation-indexed and breakeven excess returns for liquidity and compute inflationindexed bond returns due to illiquidity:

$$
\begin{aligned}
x r_{n, t+1}^{T I P S-L} & =n y_{n, t}^{T I P S, a d j}-(n-1) y_{n-1, t+1}^{T I P S, a d j}-y_{1, t}^{T I P S}, \\
x r_{n, t+1}^{b+L} & =x r_{n, t+1}^{\$}-x r_{n, t+1}^{T I P S-L} \\
r_{n, t+1}^{L} & =-(n-1) L_{n-1, t+1}+n L_{n, t} .
\end{aligned}
$$

Table V regresses quarterly excess returns (15), (16), and (17) onto the lagged liquidity-adjusted real term spread $\left(y_{n, t}^{T I P S}-L_{n, t}\right)-y_{1, t}^{T I P S}$, the lagged liquidity-adjusted breakeven term spread $\left(b_{n, t}+L_{n, t}\right)-b_{1, t}$, and the lagged estimated liquidity differential between inflation-indexed and nominal yields $L_{n, t}$. Intuitively, the three right-hand-side variables decompose the nominal term spread, used by Campbell and Shiller (1991) to predict nominal bond excess returns, into real term structure, inflation, and liquidity components. Table V reports Newey-West standard errors with three lags and one-sided bootstrap p-values accounting for generated regressors. ${ }^{17}$

\footnotetext{
${ }^{16}$ For comparison, Appendix Table A.IX reports results for non-liquidity adjusted excess returns.

${ }^{17}$ We use a non-parametric block bootstrap with block length 24 months and 2000 replications. We re-sample the data on inflation-indexed and nominal yields, liquidity variables, and inflation expectation proxies from nonoverlapping blocks of length 24 with replacement. See Horowitz (2001) for a survey of bootstrap methods with
} 
Ordinary least squares can overstate return-predictability in small samples, when the regressor is persistent and innovations are negatively correlated with returns (Stambaugh, 1999). In contrast, this correlation is typically negative for bond return predictability regressions (Bekaert, Hodrick, and Marshall, 1997). Therefore, the same small sample bias should bias us towards finding no predictability in real bond excess returns and breakeven returns.

\section{[TABLE V ABOUT HERE]}

Bootstrap p-values in Table VA show no statistically significant predictability in liquidityadjusted U.S. TIPS excess returns. Of course, the relatively short U.S. sample might bias us towards finding no predictability. Columns (1) and (2) of Panel B provide additional evidence from the cross-section of international inflation-indexed bonds and show strong evidence for excess return predictability in the U.K. The U.K. real term spread enters with a positive and significant coefficient even when controlling for liquidity. The liquidity-adjusted breakeven term spread and lagged liquidity do not enter significantly in columns (1) or (2) either in the U.S. or the U.K., as one might expect if those variables are unrelated to real interest rate risk.

Columns (3) and (4) in Tables VA and VB show that liquidity-adjusted breakeven term spreads predict breakeven excess returns with coefficients that are large, statistically significant, and similar across both countries. This empirical finding indicates that that time-varying inflation risk premia are a source of predictability in nominal bond excess returns and that the nominal term spread partly reflects time-varying inflation risk premia.

Remarkably, liquidity does not predict liquidity-adjusted real bond or breakeven excess returns in the U.S. or the U.K. The estimated liquidity differential does not appear related to fundamental bond cash-flow risk, alleviating concerns that estimated liquidity might capture time-varying

serially dependent data. 
inflation risk premia as a result of our estimation strategy.

The last two columns in Tables VA and VB show that liquidity $L_{n, t}$ predicts liquidity returns

$r_{n, t+1}^{L}$ with large and highly significant coefficients. Time-varying and predictable liquidity premia are a source of inflation-indexed bond excess return predictability both in the U.S. and the U.K. Equivalently, the liquidity component in breakeven exhibits predictable mean reversion. When liquidity in the inflation-indexed bond market is scarce, inflation-indexed bonds enjoy a higher expected return relatively to nominal bonds, rewarding investors who are willing to invest into a temporarily less liquid market.

Table V uses inflation-indexed bond returns in excess of a hypothetical real short rate. Appendix Table A.VIII shows that our results are similar if we replace TIPS returns in excess of the estimated real interest rate with nominal TIPS returns in excess of the nominal T-bill rate. Appendix Table A.VII shows that return predictability regressions are very similar if we include interaction terms in the liquidity estimation.

\section{A Economic Significance of Bond Risk Premia}

\section{[TABLE VI ABOUT HERE]}

Table VI evaluates the economic significance of time-varying real rate risk premia, inflation risk premia, and liquidity risk premia. For simplicity we refer to the expected liquidity excess return as a liquidity risk premium, the expected liquidity-adjusted breakeven return as an inflation risk premium and expected liquidity-adjusted TIPS returns as a real rate risk premium. We note that our average return calculations are based on log returns with no variance adjustments for Jensen's inequality.

By construction, the average excess return on inflation-indexed bonds equals the sum of the 
liquidity risk premium plus the real rate risk premium. Column (1) of Panel A shows that, at 99 bps, the liquidity risk premium accounts for almost one-fifth of the average realized U.S. TIPS excess return over this period. Although the average estimated inflation risk premium is economically significant at $52 \mathrm{bps}$, it is substantially smaller than the average real interest rate risk premium over the same time period. Panel B shows that at $161 \mathrm{bps}$, the average estimated U.K. liquidity risk premium is even more substantial. Interestingly, the estimated inflation risk premium in U.K. nominal bonds is negative at $-34 \mathrm{bps}$, helping to explain low average log excess returns on nominal U.K. bonds. ${ }^{18}$

Column (2) of Table VIA shows that U.S. liquidity-adjusted breakeven excess returns and liquidity-adjusted TIPS excess returns both have small and negative CAPM betas. In contrast, the beta on U.S. liquidity returns is positive and significant. The positive liquidity beta implies that TIPS tend to become illiquid relative to nominal Treasury bonds - or conversely, nominal bonds become liquid relative to TIPS - during stock market drops. ${ }^{19}$

The strong positive covariation between U.S. estimated liquidity returns and stock returns suggests that investors should earn a premium on TIPS for bearing systematic variation in liquidity. Consistent with this notion, Appendix Table A.X shows a small and insignificant market alpha for liquidity returns over our full sample. The same table shows that during the pre-crisis period, liquidity returns have no market exposure and substantial alpha, suggesting that liquidity returns compensate TIPS holders for the risk of illiquidity during dramatic falls in the stock market.

In contrast, Table VIB shows that the U.K. liquidity beta is indistinguishable from zero. The

\footnotetext{
${ }^{18}$ Our estimates suggest that the negative inflation risk premium estimated by Campbell, Sunderam and Viceira (2013) over our sample period might have been partly due to a relative TIPS liquidity premium.

${ }^{19}$ We compute CAPM betas using the stock market as the proxy for the wealth portfolio. The U.S. excess stock return is the log quarterly return on the value-weighted CRSP index, rebalanced annually, in excess of the log 3-month interest rate. The U.K. excess stock return is the log quarterly total return on the FTSE in excess of the log 3-month interest rate. Appendix Table A.X shows that raw breakeven returns exhibit a large and negative CAPM beta. Appendix Table A.XI shows that TIPS liquidity returns are not related to innovations in the Pastor and Stambaugh (2003) factor, which captures stock market liquidity, or to the Fama-French factors.
} 
CAPM beta of U.K. liquidity-adjusted breakeven returns is large, negative, and statistically significant, indicating pro-cyclical inflation expectations and nominal interest rates during our sample. Both procyclical nominal interest rates and low inflation risk premia are consistent with a view that nominal Treasuries were safe assets and provided investors with sizable diversification benefits over our sample.

The last two columns in Table VI tie our results back to the initial motivation and theory. Column (3) of Table VI reports roughly similar standard deviations for estimated real rate risk premia, inflation risk premia and liquidity risk premia. The standard deviations in column (3) are in line with the standard deviation of predicted nominal excess bond returns estimated from standard Campbell and Shiller (1991) bond return forecasting regressions (Appendix Table A.IX), so estimated components of bond excess returns are as predictable as raw excess returns.

Column (4) of Table VI shows that the nominal term spread, shown by Campbell and Shiller (1991) to forecast nominal bond excess returns, is highly correlated with estimates of both inflation risk premia and real rate risk premia. The correlations between the nominal term spread and inflation risk premia range from $71 \%$ to $85 \%$, while the correlations with real rate risk premia range from $88 \%$ to $90 \%$.

[FIGURE 5 ABOUT HERE]

Figure 5 shows predicted 3-month excess returns or real rate risk premia, inflation risk premia, and liquidity risk premia. While magnitudes may appear large, Figure 5 shows predicted 3-month returns in annualized units and not predicted 12-month returns. Figure 5A shows a small or negative U.S. inflation risk premium 2000-2006. The inflation risk premium became positive during the period of high oil prices in 2008 and fell to almost $-5 \%$ at the beginning of 2009 , just when the U.S. real rate risk premium increased sharply. 
A large and positive U.S. real interest rate risk premium during the crisis indicates that real bonds were considered risky, so a deepening of the recession was considered likely to go along with high long-term real interest rates. The liquidity risk premium on real bonds relative to nominal bonds spiked in the U.S., but not in the U.K. during the financial crisis. The U.K. liquidity risk premium even declined, suggesting that investors did not consider U.K. real bonds risky due to illiquidity.

U.S. and U.K. inflation risk premia present a contrasting picture during the financial crisis, mirroring contrasting inflation experiences. In contrast to the U.S., the U.K. inflation risk premium shot up during the financial crisis. This high inflation risk premium likely reflected the high level and volatility of U.K. inflation during the financial crisis.

\section{Conclusion}

This paper explores the sources of time variation in bond risk premia in nominal and inflationindexed bonds in the U.S. and the U.K. We find strong empirical evidence in both markets that nominal bond excess return predictability is related to time variation in inflation risk premia. Inflation risk premia exhibit significant time variation, are low on average, and take both positive and negative values in our sample. We find strong evidence in U.K. data that predictability in nominal bond excess returns is also related to time-varying real interest rate risk premia.

We find strong empirical evidence for both time-varying real rate and time-varying liquidity risk premia in inflation-indexed bonds in both markets. Liquidity risk premia in U.S. TIPS account for 99 bps of TIPS excess returns over our sample. Our results suggest that bond investors receive a liquidity discount for holding inflation-indexed bonds. However, this time-varying discount exposes them to systematic risk as measured by a positive and statistically significant CAPM beta. 
The estimated liquidity premium in U.S. TIPS yields relative to nominal yields is economically significant and strongly time-varying. We estimate a large premium early in the life of TIPS, a significant decline after 2004, and a sharp increase to over 150 bps during the height of the financial crisis in the fall of 2008 and winter of 2009. Since then, the premium has declined back to more normal levels of 50 to 70 bps. The estimated relative liquidity premium might partly reflect a convenience yield on nominal bonds (Krishnamurthy and Vissing-Jorgensen, 2012), rather than a liquidity discount specific to TIPS. In this case, TIPS are not undervalued securities, but instead investors may be willing to pay a liquidity premium on nominal Treasury bonds.

Estimated inflation risk premia, real rate risk premia and liquidity risk premia are roughly equally quantitatively important as sources of bond excess return predictability. Inflation risk premia and real rate risk premia are strongly correlated with the nominal term spread, while liquidity risk premia are not. The empirical results in this paper have important implications for modeling and understanding predictability in bond excess returns. We find an important role for time-varying real interest rate risk, which can be modeled either in a model of time-varying habit (Wachter, 2006) or in a model of time variation in expected aggregate consumption growth or its volatility (Bansal and Yaron, 2004, Bansal, Kiku, and Yaron, 2010). However, our results indicate that time-varying inflation risk is equally important for understanding the time-varying risks of nominal government bonds. A model that aims to capture predictability in nominal government bond excess returns therefore has to integrate sources of real interest rate risk and inflation risk.

Our results suggest directions for future research. Different classes of investors have different degrees of exposure to time-varying liquidity risk, real interest rate risk and inflation risk. Exposures may vary with shares of real and nominal liabilities and time horizons. Understanding the sources of bond return predictability can therefore have potentially important implications for investors' portfolio management and pension investing. 


\section{References}

Acharya, Viral V., and Lasse Heje Pedersen, 2005, Asset Pricing with Liquidity Risk, Journal Financial Economics 77, 375-410.

Amihud, Yakov, Haim Mendelson, and Lasse Heje Pedersen, 2005, Liquidity and Asset Prices, Foundations and Trends in Finance 1(4), 269-364.

Anderson, Nicola, and John Sleath, 2001, New Estimates of the U.K. Real and Nominal Yield Curves, Bank of England Working Paper, ISSN 1368-5562

Ang, Andrew, Geert Bekaert, and Min Wei, 2007, Do Macro Variables, Asset Markets, or Surveys Forecast Inflation Better?, Journal of Monetary Economics 54:1163-1212.

Ang, Andrew, Geert Bekaert, and Min Wei, 2008, The Term Structure of Real Rates and Expected Inflation, Journal of Finance 63(2), 797-849.

Bansal, Ravi, Dana Kiku, and Amir Yaron, 2010, Long Run Risks, the Macroeconomy, and Asset Prices, American Economic Review 100(2), 542-546.

Bansal, Ravi, and Ivan Shaliastovich, 2013, A Long-Run Risks Explanation of Predictability Puzzles in Bond and Currency Markets, Review of Financial Studies 26(1), 1-33.

Bansal, Ravi, and Amir Yaron, 2004, Risks for the Long Run: A Potential Resolution of Asset Pricing Puzzles, Journal of Finance 59, 1481-1509.

Barr, David G., and John Y. Campbell, 1997, Inflation, Real Interest Rates, and the Bond Market: A Study of UK Nominal and Index-Linked Government Bond Prices, Journal of Monetary Economics 39, 361-383.

Bauer, Michael D., Glenn D. Rudebusch, and Jing Cynthia Wu, 2012, Correcting Estimation Bias in Dynamic Term Structure Models, Journal of Business and Economic Statistics, 30(3), 454-467.

Bekaert, Geert, Robert J. Hodrick, and David A. Marshall, 1997, On Biases in Tests of the Expectations Hypothesis of the Term Structure of Interest Rates, Journal of Financial Economics 44, 309-348.

Bitsberger, Timothy, 2003, Why the Treasury Issues TIPS, Chart Presentation of Deputy Assistant Secretary for Federal Finance Timothy S. Bitsberger To the Bond Market Association's Inflation-Linked Securities Conference New York, NY, available at http://www.treasury.gov/presscenter/press-releases/Pages/js505.aspx.

Buraschi, Andrea, and Alexei Jiltsov, 2005, Inflation Risk Premia and the Expectations Hypothesis, Journal of Financial Economics 75, 429-490. 
Buraschi, Andrea, and Davide Menini, 2002, Liquidity Risk and Specialness, Journal of Financial Economics 64, 243-284.

Campbell, John Y., and John H. Cochrane, 1999, By Force of Habit: A Consumption-Based Explanation of Aggregate Stock Market Behavior, Journal of Political Economy 107, 205251.

Campbell, John Y. and Robert J. Shiller, 1991, Yield Spreads and Interest Rate Movements: A Bird's Eye View, Review of Economic Studies 58, 495-514.

Campbell, John Y., and Robert J. Shiller, 1996, A Scorecard for Indexed Government Debt, in Ben S. Bernanke and Julio Rotemberg, ed.: National Bureau of Economic Research Macroeconomics Annual 1996 (MIT Press).

Campbell, John Y., Robert J. Shiller, and Luis M. Viceira, 2009, Understanding Inflation-Indexed Bond Markets, in David Romer and Justin Wolfers, ed.: Brookings Papers on Economic Activity: Spring 2009 (Brookings Institution Press).

Campbell, John Y., Adi Sunderam, and Luis M. Viceira, 2013, Inflation Bets or Deflation Hedges? The Changing Risks of Nominal Bonds, Manuscript, Harvard University.

Campbell, John Y., Carolin Pflueger, and Luis M. Viceira, 2013, Monetary Policy Drivers of Bond and Equity Risks, Manuscript, Harvard University and University of British Columbia.

Campbell, John Y., and Luis M. Viceira, 2001, Who Should Buy Long-Term Bonds?, American Economic Review 91, 99-127.

Chen, R.-R., B. Liu, and X. Cheng, 2010, Pricing the Term Structure of Inflation Risk Premia: Theory and Evidence from TIPS, Journal of Empirical Finance 17:702-21.

Christensen, Jens E., and Gillan, James M., 2011, A Model-Independent Maximum Range for the Liquidity Correction of TIPS Yields, manuscript, Federal Reserve Bank of San Francisco.

Christensen, Jens E., Jose A. Lopez, and Glenn D. Rudebusch, 2010, Inflation Expectations and Risk Premiums in an Arbitrage-Free Model of Nominal and Real Bond Yields, Journal of Money, Credit and Banking 42(6), 143-178.

Cochrane, John H., and Monika Piazzesi, 2005, Bond Risk Premia, American Economic Review 95(1):138-160.

D'Amico, Stefania, Don H. Kim, and Min Wei, 2008, Tips from TIPS: The Informational Content of Treasury Inflation-Protected Security Prices, BIS Working Papers, No 248.

Dudley, William C., Jennifer Roush, and Michelle Steinberg Ezer, 2009, The Case for TIPS: An Examination of the Costs and Benefits, Economic Policy Review 15(1), 1-17.

Duffie, Darrel, 1996, Special Repo Rates, Journal of Finance 51(2), 493-526. 
Duffie, Darrel, Nicolae Gârleanu, and Lasse Heje Pedersen, 2005, Over-the-Counter Markets, Econometrica 73(6), 1815-1847.

Duffie, Darrel, Nicolae Gârleanu, and Lasse Heje Pedersen, 2007, Valuation in Over-the-Counter Markets, Review of Financial Studies 20(5), 1865-1900.

Evans, Martin D., 1998, Real Rates, Expected Inflation and Inflation Risk Premia, Journal of Finance 53(1):187-218.

Fama, Eugene F., and Robert R. Bliss, 1987, The Information in Long-Maturity Forward Rates, American Economic Review 77, 680-692.

Fleckenstein, Matthias, Francis A. Longstaff, and Hanno Lustig, 2013, The TIPS-Treasury Bond Puzzle, Journal of Finance, forthcoming.

Fleming, Michael J., and Neel Krishnan, 2009, The Microstructure of the TIPS Market, FRB of New York Staff Report, No. 414.

Fontaine, Jean-Sebastien, and Rene Garcia, 2012, Bond Liquidity Premia, Review of Financial Studies, 25(4), 1207-1254.

Gabaix, Xavier, 2012, Variable Rare Disasters: An Exactly Solved Framework for Ten Puzzles in Macro-Finance, Quarterly Journal of Economics 127, 645-700.

Gârleanu, Nicolae, and Lasse H. Pedersen, 2011, Margin-Based Asset Pricing and Deviations from the Law of One Price, Review of Financial Studies 24(6), 1980-2022.

Gürkaynak, Refet S., Brian Sack, and Jonathan H. Wright, 2007, The U.S. Treasury yield curve: 1961 to the present, Journal of Monetary Economics 54(8), 2291-2304.

Gürkaynak, Refet S., Brian Sack, and Jonathan H. Wright, 2010, The TIPS Yield Curve and Inflation Compensation, American Economic Journal: Macroeconomics 2(1), 70-92.

Granger, C.W.J., and P. Newbold, 1974, Spurious Regressions in Econometrics, Journal of Econometrics 2, 111-120.

Greenwood, Robin, and Dimitri Vayanos, 2008, Bond Supply and Excess Bond Returns, NBER Working Paper Series, No. 13806.

Greenwood, Robin, and Dimitri Vayanos, 2010, Price Pressure in the Government Bond Market, American Economic Review 100(2), 585-90.

Grishchenko, Olesya V., Joel M. Vanden, and Jianing Zhang, 2011, The Informational Content of the Embedded Deflation Option in TIPS, Finance and Economics Discussion Series, Federal Reserve Board.

Hamilton, James, 1994, Time Series Analysis, Princeton University Press. 
Hamilton, James D., and Jing (Cynthia) Wu, 2012, The Effectiveness of Alternative Monetary Policy Tools in a Zero Lower Bound Environment, Journal of Money, Credit and Banking 44, $3-46$.

Haubrich, Joseph G., George G. Pennacchi, and Peter H. Ritchken, 2012, Inflation Expectations, Real Rates, and Risk Premia: Evidence from Inflation Swaps, Review of Financial Studies, 25(5), 1588-1629

Horowitz, J.L., 2001, The Bootstrap, in J.J. Heckman and E.E. Leamer, ed: Handbook of Econometrics Vol. 5 (Amsterdam: North-Holland Publishing Co.).

Hu, Grace Xing, Jun Pan, and Jiang Wang, 2013, Noise as Information for Illiquidity, Journal of Finance, forthcoming.

Huang, Jing-Zhi, and Zhan Shi, 2012, "Understanding Term Premia on Real Bonds", Manuscript, Penn State University

Krishnamurthy, Arvind, 2002, The Bond/Old-Bond Spread, Journal of Financial Economics 66(2), 463-506.

Krishnamurthy, Arvind, and Annette Vissing-Jorgensen, 2012, The Aggregate Demand for Treasury Debt, Journal of Political Economy 120(2), 233-267.

Modigliani, Franco, and Richard Sutch, 1966, Innovations in Interest-Rate Policy, American Economic Review 56, 178-197.

Pastor, Lubos, and Robert F. Stambaugh, 2003, Liquidity Risk and Expected Stock Returns, Journal of Political Economy 111, 642-685.

Phillips, P.C.B., 1986, Understanding Spurious Regressions in Econometrics, Journal of Econometrics 33(3), 311-340.

Piazzesi, Monika and Martin Schneider, 2007, Equilibrium Yield Curves, in D. Acemoglu, K. Rogoff, and M. Woodford (eds.) NBER Macroeconomics Annual 2006, 317-363, MIT Press, Cambridge, MA.

Pflueger, Carolin E., and Luis M. Viceira, 2011, Inflation-Indexed Bonds and the Expectations Hypothesis, Annual Review of Financial Economics 3:139-158.

Roll, Richard, 2004, Empirical TIPS, Financial Analysts Journal 60, 31-53.

Stock, James, and Mark Watson, 1999, Forecasting Inflation, Journal of Monetary Economics 44, 293-335.

Stambaugh, Robert, 1999, Predictive Regressions, Journal of Financial Economics 54, 375-421.

Vayanos, Dimitri, 2004, Flight to Quality, Flight to Liquidity, and the Pricing of Risk, NBER Working Paper Series, No. 10327. 
Vayanos, Dimitri, and Jean-Luc Vila, 2009, A Preferred-Habitat Model of the Term Structure of Interest Rates, NBER Working Paper Series, No. 15487.

Vayanos, Dimitri, and Tan Wang, 2007, Search and Endogenous Concentration of Liquidity in Asset Markets, Journal of Economic Theory 136, 66 -104.

Viceira, Luis M, 2001, The Harvard Management Company and Inflation-Protected Bonds, HBS Case \# 201-053.

Viceira, Luis M., 2011, Discussion of 'Why Does The Treasury Issue TIPS? The TIPS-Treasury Bond Puzzle', slide presentation prepared for the NBER Asset Pricing Group Meeting of April 29, 2011, Chicago. Available upon request.

Wachter, Jessica A., 2003, Risk Aversion and Allocation to Long-Term Bonds, Journal of Economic Theory 112, 325-333.

Wachter, Jessica A., 2006, A Consumption-Based Model of the Term Structure of Interest Rates,, Journal of Financial Economics 79, 365-399.

Weill, Pierre-Olivier, 2008, Liquidity Premia in Dynamic Bargaining Markets, Journal of Economic Theory 140, 66-96.

Wright, Jonathan H., 2009, Comment on Understanding Inflation-Indexed Bond Markets, in David Romer and Justin Wolfers, ed.: Brookings Papers on Economic Activity: Spring 2009 (Brookings Institution Press). 
Table I: Summary Statistics.

Nominal and inflation-indexed bond yields, excess returns, inflation expectation proxies and liquidity proxies. U.S. 10 year nominal and TIPS yields from Gurkaynak, Sack, and Wright (2010). U.K. 20 year nominal and inflation-indexed yields from Anderson and Sleath (2001). U.S. three-month log excess returns (1996.-2010.12) and U.K. three-month log excess returns (2000.2-2010.12) are approximated using zero-coupon $\log$ yields. U.S. survey inflation is the median 10 year CPI inflation forecast from the Survey of Professional Forecasters. The Chicago Fed National Activity Index (CFNAI) is as in Stock and Watson (1999). U.K. survey inflation reflects Bank of England Public Attitudes Survey 12 month inflation expectations. U.S. asset-swap spread (2004.1-2010.12), U.S. difference between synthetic and cash breakeven (2004.7-2010.12), and U.K. 3-month GBP LIBOR minus general collateral (GC) spread capture cost of arbitraging between nominal and inflation-indexed bonds. We normalize the maxima of relative transaction volumes to zero. The U.K. off-the-run spread reflects the spread between a fitted 10 year nominal par yield and the generic 10 year nominal U.K. bond yield from Bloomberg. Spreads and zero-coupon yields continously compounded in annualized percent.

\begin{tabular}{lccccc} 
Panel A: U.S. (1999.3-2010.12) & & Mean & Std & Min & Max \\
\hline Nominal Yields & $y_{n, t}^{\Phi}$ & 4.68 & 0.87 & 2.66 & 6.70 \\
Inflation-Indexed Yields & $y_{n, t}^{T I P S}$ & 2.44 & 0.91 & 0.59 & 4.29 \\
Breakeven & $b_{n, t}$ & 2.24 & 0.39 & 0.39 & 2.87 \\
Nominal Excess Ret. & $x r_{n, t+1}^{\$}$ & 4.19 & 8.75 & -41.89 & 56.62 \\
Infl.-Indexed Excess Ret. & $x r_{n, t+1}^{T I P S}$ & 4.66 & 7.63 & -64.91 & 58.03 \\
Breakeven Excess Ret. & $x r_{n, t+1}^{b}$ & -0.48 & 7.30 & -42.62 & 74.33 \\
& & & & & \\
Survey Inflation & $\pi^{E}$ & 2.47 & 0.07 & 2.2 & 2.55 \\
Chicago Fed Nat. Activity & CFNAI & -0.37 & 0.96 & -4.46 & 1.08 \\
Off-the-Run Spr. & & 0.21 & 0.11 & 0.07 & 0.63 \\
Log Transaction Vol. & & -0.57 & 0.44 & -1.44 & 0.00 \\
Asset-Swap Spr. & & 0.43 & 0.21 & 0.21 & 1.34 \\
Synthetic - Cash & & 0.32 & 0.17 & 0.11 & 1.13 \\
& & & & & \\
Panel B: U.K. (1999.11-2010.12) & & Mean & Std & Min & Max \\
\hline Nominal Yields & $y_{n, t}^{\Phi}$ & 4.41 & 0.25 & 3.79 & 5.01 \\
Inflation-Indexed Yields & $y_{n, t}^{T I P S}$ & 1.53 & 0.52 & 0.57 & 2.44 \\
Breakeven & $b_{n, t}$ & 2.88 & 0.46 & 2.14 & 3.95 \\
Nominal Excess Ret. & $x r_{n, t+1}^{\$}$ & 0.50 & 10.09 & -49.25 & 50.08 \\
Infl.-Indexed Excess Ret. & $x r_{n, t+1}^{T I P S}$ & 2.46 & 8.39 & -65.78 & 32.85 \\
Breakeven Excess Ret. & $x r_{n, t+1}^{b}$ & -1.96 & 7.96 & -37.39 & 66.96 \\
& & & & \\
Survey Inflation & $\pi^{E}$ & 2.52 & 0.57 & 1.50 & 4.40 \\
Off-the-Run Spr. & & 0.04 & 0.05 & -0.06 & 0.32 \\
Log Transaction Vol. & & -0.65 & 0.29 & -1.36 & 0.00 \\
LIBOR-GC Spr. & & 0.35 & 0.36 & 0.11 & 2.25 \\
\hline
\end{tabular}


Table II: Estimating Differential Liquidity.

We regress the difference between nominal and inflation-indexed bond yields (breakeven inflation) onto liquidity proxies. The variables are as described in Table I. Newey-West standard errors with three lags in parentheses. The p-value of the F-test for no predictability is shown. ${ }^{*}$ and ${ }^{* *}$ denote significance at the $5 \%$ and $1 \%$ level, respectively.

Panel A: U.S. (1999.3-2010.12)

\begin{tabular}{|c|c|c|c|c|c|c|c|}
\hline$y_{n, t}^{\$}-y_{n, t}^{T I P S}$ & (1) & $(2)$ & $(3)$ & $(4)$ & $(5)$ & $(6)$ & $(7)$ \\
\hline Off-the-Run Spr. & & $\begin{array}{c}-2.07^{* *} \\
(0.26)\end{array}$ & $\begin{array}{c}-1.97^{* *} \\
(0.26)\end{array}$ & $\begin{array}{c}-0.87^{*} \\
(0.42)\end{array}$ & $\begin{array}{c}-1.27^{* *} \\
(0.32)\end{array}$ & & $\begin{array}{c}-1.46^{* *} \\
(0.42)\end{array}$ \\
\hline Asset-Swap Spr. & & & $\begin{array}{l}-0.27 \\
(0.24)\end{array}$ & $\begin{array}{c}-0.86^{* *} \\
(0.31)\end{array}$ & & & $\begin{array}{c}0.78 \\
(0.93)\end{array}$ \\
\hline Transaction Vol. & & & & $\begin{array}{l}0.33^{* *} \\
(0.10)\end{array}$ & $\begin{array}{l}0.24^{* *} \\
(0.07)\end{array}$ & & $\begin{array}{c}0.09 \\
(0.09)\end{array}$ \\
\hline Synthetic-Cash & & & & & $\begin{array}{c}-1.13^{* *} \\
(0.28)\end{array}$ & & \\
\hline Survey Inflation & $\begin{array}{c}0.04 \\
(0.46)\end{array}$ & $\begin{array}{c}0.70 \\
(0.49)\end{array}$ & $\begin{array}{c}0.50 \\
(0.49)\end{array}$ & $\begin{array}{c}0.17 \\
(0.41)\end{array}$ & $\begin{array}{c}0.56 \\
(0.39)\end{array}$ & $\begin{array}{c}0.80 \\
(1.62)\end{array}$ & $\begin{array}{c}0.29 \\
(0.82)\end{array}$ \\
\hline CFNAI & $\begin{array}{l}0.25^{* *} \\
(0.05)\end{array}$ & $\begin{array}{l}0.11^{* *} \\
(0.04)\end{array}$ & $\begin{array}{l}0.08^{* *} \\
(0.04)\end{array}$ & $\begin{array}{l}0.12^{* *} \\
(0.03)\end{array}$ & $\begin{array}{l}0.10^{* *} \\
(0.03)\end{array}$ & $\begin{array}{l}0.28^{* *} \\
(0.05)\end{array}$ & $\begin{array}{l}0.18^{* *} \\
(0.04)\end{array}$ \\
\hline $\mathrm{p}$-value & 0.00 & 0.00 & 0.00 & 0.00 & 0.00 & 0.00 & 0.00 \\
\hline$R^{2}$ & 0.39 & 0.60 & 0.61 & 0.66 & 0.70 & 0.30 & 0.61 \\
\hline ADF of Residuals & $-4.17^{* *}$ & $-4.45^{* *}$ & $-4.27^{* *}$ & $-4.73^{* *}$ & $-5.08^{* *}$ & $-4.58^{* *}$ & $-4.75^{* *}$ \\
\hline Period & Full & Full & Full & Full & Full & 1999.3 & 2006.12 \\
\hline \multicolumn{8}{|c|}{ Panel B: U.K. (1999.11-2010.12) } \\
\hline$y_{n, t}^{\$}-y_{n, t}^{T I P S}$ & $(1)$ & $(2)$ & $(3)$ & $(4)$ & & $(5)$ & $(6)$ \\
\hline Off-the-Run Spr. & & $\begin{array}{l}-0.45 \\
(0.88)\end{array}$ & $\begin{array}{l}-0.89 \\
(1.14)\end{array}$ & $\begin{array}{l}-1.25 \\
(0.94)\end{array}$ & & & $\begin{array}{c}-3.19^{* *} \\
(0.57)\end{array}$ \\
\hline LIBOR-GC Spr. & & & $\begin{array}{c}0.16 \\
(0.20)\end{array}$ & $\begin{array}{c}0.18 \\
(0.18)\end{array}$ & & & $\begin{array}{c}0.39 \\
(0.20)\end{array}$ \\
\hline Transaction Vol. & & & & $\begin{array}{l}0.78^{* *} \\
(0.17)\end{array}$ & & & $\begin{array}{l}0.47^{* *} \\
(0.11)\end{array}$ \\
\hline Survey Inflation & $\begin{array}{c}0.57^{* *} \\
(0.06)\end{array}$ & $\begin{array}{l}0.59^{* *} \\
(0.06)\end{array}$ & $\begin{array}{l}0.56^{* *} \\
(0.06)\end{array}$ & $\begin{array}{l}0.28^{* *} \\
(0.08)\end{array}$ & & $\begin{array}{l}0.55^{* *} \\
(0.12)\end{array}$ & $\begin{array}{l}0.27^{* *} \\
(0.08)\end{array}$ \\
\hline $\mathrm{p}$-value & 0.00 & 0.00 & 0.00 & 0.00 & & 0.00 & 0.00 \\
\hline$R^{2}$ & 0.51 & 0.51 & 0.52 & 0.65 & & 0.31 & 0.67 \\
\hline ADF of Residuals & $-3.86^{*}$ & $-3.88^{*}$ & $-3.92^{*}$ & $-4.14^{* *}$ & & $-3.88^{*}$ & $-4.07^{* *}$ \\
\hline Period & Full & Full & Full & Full & & 1999.11 & 2006.12 \\
\hline
\end{tabular}


Table III: Breakeven Inflation onto Relative Inflation-Indexed Bond Supply.

We regress the difference between nominaland inflation-indexed yields (breakeven inflation) onto relative supply of inflation-indexed bonds for the U.S. (Panel A) and for the U.K. (Panel B), while controlling for liquidity variables and a time trend. Supply $y_{t}$ denotes the face value of inflation-indexed bonds outstanding relative to all nominal and inflation-indexed bonds outstanding. $\Delta$ Supplyt denotes the issuance of inflation-indexed bonds relative to all nominal and inflation-indexed bonds. $\varepsilon_{t}^{\text {Supply }}$ is obtained as the residual in a 12-lag monthly autoregression of $\Delta$ Supply $y_{t}-\Delta$ Supply $_{t-12}\left(\Delta\right.$ Supply $\left._{t}\right)$ in the U.S. (U.K.). Newey-West standard errors with three lags in parentheses. The p-value of the F-test for no predictability is shown. ${ }^{*}$ and ${ }^{* *}$ denote significance at the $5 \%$ and $1 \%$ level, respectively.

\begin{tabular}{lcccc} 
Panel A: U.S. & 2000.2-2010.12) & & \\
$y_{n, t}^{\$}-y_{n, t}^{T I P S}$ & $(1)$ & $(2)$ & $(3)$ & $(4)$ \\
\hline Supplyt & $0.05^{* *}$ & & & 0.03 \\
& $(0.01)$ & & & $(0.02)$ \\
$\Delta$ Supply $_{t}$ & & 0.01 & & -0.00 \\
& & $(0.01)$ & & $(0.01)$ \\
$\varepsilon_{t}^{\text {Supply }}$ & & & 0.01 & 0.01 \\
& & & $(0.01)$ & $(0.01)$ \\
Off-the-run Spr. & & & & $-0.95^{*}$ \\
& & & & $(0.44)$ \\
Asset-Swap-Spr. & & & & $-1.05^{* *}$ \\
& & & & $(0.31)$ \\
Transaction Vol. & & & & 0.07 \\
& & & & $(0.16)$ \\
Survey Inflation & 0.57 & -0.07 & 0.05 & 0.68 \\
& $(0.45)$ & $(0.49)$ & $(0.48)$ & $(0.56)$ \\
CFNAI & $0.32^{* *}$ & $0.26^{* *}$ & $0.27^{* *}$ & $0.12^{* *}$ \\
& $(0.05)$ & $(0.05)$ & $(0.05)$ & $(0.03)$ \\
month & & & & 0.00 \\
& & & & $(0.00)$ \\
\hline p-value & 0.00 & 0.00 & 0.00 & 0.00 \\
$R^{2}$ & 0.53 & 0.43 & 0.43 & 0.70 \\
Sample & & $2000.2-2010.12$ & \\
\hline
\end{tabular}


Table III (continued)

\begin{tabular}{|c|c|c|c|c|c|}
\hline$y_{n, t}^{\$}-y_{n, t}^{T I P S}$ & $(1)$ & (2) & $(3)$ & $(4)$ & (5) \\
\hline Supply $y_{t}$ & $\begin{array}{l}0.07^{*} \\
(0.03)\end{array}$ & & & $\begin{array}{c}0.03 \\
(0.03)\end{array}$ & $\begin{array}{c}0.01 \\
(0.03)\end{array}$ \\
\hline$\Delta S u p p l y_{t}$ & & $\begin{array}{c}0.00 \\
(0.02)\end{array}$ & & $\begin{array}{l}-0.00 \\
(0.05)\end{array}$ & $\begin{array}{l}-0.02 \\
(0.05)\end{array}$ \\
\hline$\varepsilon_{t}^{\text {Supply }}$ & & & $\begin{array}{c}0.01 \\
(0.02)\end{array}$ & $\begin{array}{c}0.00 \\
(0.05)\end{array}$ & $\begin{array}{c}0.02 \\
(0.05)\end{array}$ \\
\hline Off-the-run Spr. & & & & & $\begin{array}{l}-0.11 \\
(0.11)\end{array}$ \\
\hline LIBOR-GC Spr. & & & & & $\begin{array}{c}0.02 \\
(0.03)\end{array}$ \\
\hline Transaction Vol. & & & & & $\begin{array}{c}-0.00^{* *} \\
(0.00)\end{array}$ \\
\hline Survey Inflation & $\begin{array}{l}0.11^{* *} \\
(0.02)\end{array}$ & $\begin{array}{l}0.14^{* *} \\
(0.01)\end{array}$ & $\begin{array}{l}0.14^{* *} \\
(0.01)\end{array}$ & $\begin{array}{l}0.04^{* *} \\
(0.02)\end{array}$ & $\begin{array}{c}0.06^{* *} \\
(0.02)\end{array}$ \\
\hline month & & & & $\begin{array}{l}0.01^{* *} \\
(0.00)\end{array}$ & $\begin{array}{l}0.01^{* *} \\
(0.00)\end{array}$ \\
\hline p-value & 0.00 & 0.00 & 0.00 & 0.00 & 0.00 \\
\hline$R^{2}$ & 0.54 & 0.51 & 0.51 & 0.87 & 0.88 \\
\hline Sample & & $1986.1-$ & 2010.12 & & $1999.11-2010.12$ \\
\hline
\end{tabular}


Table IV: Excess Bond Returns onto Relative Supply of Inflation-Indexed Bonds.

We regress overlapping 3-month nominal, inflation-indexed and breakeven log excess bond returns onto measures of relative supply as defined in Table III while controlling for the nominal term spread, the TIPS term spread and the breakeven term spread and liquidity as estimated in Table II(4). Newey-West standard errors with three lags are provided in parentheses. The p-value of the F-test of no predictability is shown. ${ }^{*}$ and ${ }^{* *}$ denote significance at the $5 \%$ and $1 \%$ level, respectively.

Panel A: U.S. (2000.5-2010.12)

\begin{tabular}{lcccc} 
& $(1)$ & $(2)$ & $(3)$ & $(4)$ \\
& $x r_{n, t+1}^{\$}$ & $x r_{n, t+1}^{\$}$ & $x r_{n, t+1}^{T I P S}$ & $x r_{n, t+1}^{b}$ \\
\hline Supplyt & -0.21 & -0.38 & 0.04 & -0.42 \\
& $(0.73)$ & $(0.68)$ & $(0.71)$ & $(0.73)$ \\
$\Delta$ Supply $_{t}$ & 0.26 & 0.22 & 0.28 & -0.06 \\
& $(0.55)$ & $(0.54)$ & $(0.41)$ & $(0.30)$ \\
$\varepsilon_{t}^{\text {Supply }}$ & -0.00 & -0.00 & -0.00 & -0.00 \\
& $(0.00)$ & $(0.00)$ & $(0.00)$ & $(0.00)$ \\
$L_{n, t}$ & 1.64 & 7.03 & 18.02 & -10.99 \\
& $(9.87)$ & $(11.82)$ & $(10.20)$ & $(9.82)$ \\
$y_{n, t}^{\$}-y_{1, t}^{\$}$ & 2.11 & & & \\
$y_{n, t}^{T I P S}-y_{1, t}^{T I P S}$ & $(1.41)$ & & & \\
$b_{n, t}-b_{1, t}$ & & 0.77 & 2.53 & -1.76 \\
& & $(2.12)$ & $(1.39)$ & $(1.57)$ \\
\hline p-value & & 4.18 & -2.40 & $6.58^{*}$ \\
$R^{2}$ & 0.39 & 0.44 & 0.01 & 0.03 \\
Sample & 0.05 & 0.05 & 0.21 & 0.20 \\
\hline
\end{tabular}

Panel B: U.K. (1986.4-2010.12 and 2000.2-2010.12)

\begin{tabular}{|c|c|c|c|c|c|c|c|c|}
\hline & $\begin{array}{c}(1) \\
x r_{n, t+1}^{\$}\end{array}$ & $\begin{array}{c}(2) \\
x r_{n, t+1}^{\$}\end{array}$ & $\begin{array}{c}(3) \\
x r_{n, t+1}^{T I P S}\end{array}$ & $\begin{array}{c}(4) \\
x r_{n, t+1}^{b}\end{array}$ & $\begin{array}{c}(5) \\
x r_{n, t+1}^{\$}\end{array}$ & $\begin{array}{c}(6) \\
x r_{n, t+1}^{\$}\end{array}$ & $\begin{array}{c}(7) \\
x r_{n, t+1}^{T I P S}\end{array}$ & $\begin{array}{c}(8) \\
x r_{n, t+1}^{b}\end{array}$ \\
\hline \multirow[t]{2}{*}{ Supply } & -1.26 & -1.11 & -0.24 & -0.87 & -1.42 & -1.58 & -1.90 & 0.33 \\
\hline & (1.09) & (1.06) & $(0.78)$ & (0.99) & (1.67) & (1.69) & (1.69) & $(2.05)$ \\
\hline \multirow[t]{2}{*}{$\Delta$ Supply $_{t}$} & -3.05 & -3.70 & -3.79 & 0.09 & 3.55 & 2.72 & 3.51 & -0.79 \\
\hline & $(5.78)$ & $(5.92)$ & $(3.23)$ & $(5.39)$ & $(5.39)$ & $(5.46)$ & $(3.73)$ & $(5.24)$ \\
\hline \multirow{2}{*}{$\varepsilon_{t}^{\text {Supply }}$} & 2.46 & 2.94 & 3.73 & -0.79 & -4.82 & -4.10 & -3.91 & -0.19 \\
\hline & $(5.94)$ & (6.04) & (3.34) & $(5.53)$ & $(5.68)$ & (5.68) & $(3.96)$ & $(5.67)$ \\
\hline \multirow[t]{2}{*}{$L_{n, t}$} & & & & & -10.77 & -7.97 & -13.26 & 5.29 \\
\hline & & & & & (14.11) & (14.61) & $(8.45)$ & (11.21) \\
\hline \multirow{2}{*}{$y_{n, t}^{\$}-y_{1, t}^{\$}$} & $3.02^{*}$ & & & & 2.05 & & & \\
\hline & $(1.52)$ & & & & (1.74) & & & \\
\hline \multirow{2}{*}{$y_{n, t}^{T I P S}-y_{1, t}^{T I P S}$} & & 0.01 & $3.63^{*}$ & -3.62 & & 0.02 & 2.76 & -2.75 \\
\hline & & $(3.27)$ & $(1.75)$ & $(2.48)$ & & $(2.82)$ & (1.86) & $(2.15)$ \\
\hline \multirow[t]{2}{*}{$b_{n, t}-b_{1, t}$} & & 6.70 & -2.30 & $9.00^{* *}$ & & 4.40 & 0.03 & 4.37 \\
\hline & & $(3.73)$ & $(2.00)$ & (3.01) & & $(4.38)$ & $(2.47)$ & $(2.62)$ \\
\hline p-value & 0.17 & 0.20 & 0.23 & 0.03 & 0.32 & 0.41 & 0.15 & 0.35 \\
\hline$R^{2}$ & 0.06 & 0.07 & 0.05 & 0.10 & 0.07 & 0.08 & 0.06 & 0.05 \\
\hline Sample & \multicolumn{4}{|c|}{$1986.4-2010.12$} & \multicolumn{4}{|c|}{$2000.2-2010.12$} \\
\hline
\end{tabular}


Table V: Liquidity-Adjusted Bond Return Predictability.

We predict 3-month overlapping liquidity-adjusted excess log returns of inflation-indexed bonds and of nominal bonds in excess of inflation-indexed bonds using the liquidity-adjusted inflation-indexed term spread, the liquidity-adjusted breakeven term spread, and the liquidity differential $L_{n, t} . L_{n, t}$ is estimated as the negative of the variation explained by liquidity variables in Table II(4). $r_{n, t+1}^{L}$ is the return on inflation-indexed bonds due to illiquidity. Newey-West standard errors with three lags in parentheses. The p-value of the F-test for no predictability is shown. We show one-sided bootstrap p-values from 2000 replications to account for the fact that liquidity is estimated. We use block bootstrap with block length 24 months.

Panel A: U.S. (1999.6-2010.12)

\begin{tabular}{|c|c|c|c|c|c|c|c|}
\hline & & $\begin{array}{c}(1) \\
x r_{n, t+1}^{T I P S-L}\end{array}$ & $\begin{array}{c}(2) \\
x r_{n, t+1}^{T I P S-L}\end{array}$ & $\begin{array}{c}(3) \\
x r_{n, t+1}^{b+L}\end{array}$ & $\begin{array}{c}(4) \\
x r_{n, t+1}^{b+L}\end{array}$ & $\begin{array}{c}(5) \\
r_{n, t+1}^{L}\end{array}$ & $\begin{array}{c}(6) \\
r_{n, t+1}^{L}\end{array}$ \\
\hline \multirow[t]{3}{*}{$\left(y_{n, t}^{T I P S}-L_{n, t}\right)-y_{1, t}^{T I P S}$} & & 3.04 & 2.31 & & $\begin{array}{l}n, t+1 \\
-1.31\end{array}$ & & $\begin{array}{l}n, l+1 \\
0.24\end{array}$ \\
\hline & Newey-West SE & $(1.35)$ & $(1.81)$ & & $(1.53)$ & & $(0.66)$ \\
\hline & Bootstrap p-value & $15.3 \%$ & $23.9 \%$ & & $33.8 \%$ & & $44.5 \%$ \\
\hline \multirow[t]{3}{*}{$\left(b_{n, t}+L_{n, t}\right)-b_{1, t}$} & & & -0.22 & 4.55 & 5.20 & & -0.87 \\
\hline & Newey-West SE & & $(2.91)$ & $(1.75)$ & $(1.75)$ & & $(1.74)$ \\
\hline & Bootstrap p-value & & $17.9 \%$ & $0.1 \%$ & $0.0 \%$ & & $32.5 \%$ \\
\hline \multirow[t]{3}{*}{$L_{n, t}$} & & & 6.88 & & -6.76 & 11.49 & 11.03 \\
\hline & Newey-West SE & & $(10.14)$ & & $(7.50)$ & $(2.92)$ & $(3.53)$ \\
\hline & Bootstrap p-value & & $23.0 \%$ & & $15.5 \%$ & $0.1 \%$ & $0.1 \%$ \\
\hline \multirow[t]{3}{*}{ Const. } & & -0.00 & -0.01 & -0.01 & 0.01 & -0.02 & -0.02 \\
\hline & Newey-West SE & $(0.01)$ & $(0.02)$ & $(0.00$ & $(0.01)$ & $(0.01)$ & $(0.01)$ \\
\hline & Bootstrap p-value & $68.7 \%$ & $10.0 \%$ & $14.6 \%$ & $6.4 \%$ & $11.6 \%$ & $15.9 \%$ \\
\hline $\mathrm{p}$-value & & 0.03 & 0.16 & 0.01 & 0.02 & 0.00 & 0.00 \\
\hline$R^{2}$ & & 0.06 & 0.07 & 0.08 & 0.13 & 0.17 & 0.17 \\
\hline Sample & & \multicolumn{6}{|c|}{$1999.6-2010.12$} \\
\hline
\end{tabular}

Panel B: U.K. (2000.2-2010.12)

(1) TIPS $-L$ $x r_{n, t+1}^{T}$ $\left(y_{n, t}^{T I P S}-L_{n, t}\right)-y_{1, t}^{T T P S} \quad$ Newey-West SE Bootstrap p-value

$\left(b_{n, t}+L_{n, t}\right)-b_{1, t}$

$L_{n, t}$

Const.

\begin{tabular}{lrr} 
& Newey-West SE & $(0.01)$ \\
& Bootstrap p-value & $31.7 \%$ \\
\hline p-value & & 0.02 \\
$R^{2}$ & 0.06 \\
Sample & &
\end{tabular}

\begin{tabular}{cccccc}
$r_{n, t+1}$ & $x r_{n, t+1}$ & $x r_{n, t+1}$ & $x r_{n, t+1}$ & $r_{n, t+1}$ & $r_{n, t+1}$ \\
\hline 4.99 & 5.52 & & -4.76 & & -2.44 \\
$(2.13)$ & $(2.71)$ & & $(3.16)$ & & $(1.75)$ \\
$4.1 \%$ & $4.2 \%$ & & $4.2 \%$ & & $9.0 \%$ \\
& -4.28 & 4.59 & 8.38 & & 4.14 \\
& $(3.10)$ & $(3.77)$ & $(4.20)$ & & $(2.42)$ \\
& $24.0 \%$ & $0.7 \%$ & $0.8 \%$ & & $17.6 \%$ \\
& -20.42 & & 14.16 & 18.67 & 17.93 \\
& $(12.02)$ & & $(14.17)$ & $(7.15)$ & $(7.24)$ \\
& $8.3 \%$ & & $15.7 \%$ & $0.0 \%$ & $0.0 \%$ \\
0.00 & 0.04 & -0.01 & -0.04 & -0.02 & -0.03 \\
$(0.01)$ & $(0.02)$ & $(0.01)$ & $(0.02)$ & $(0.01)$ & $(0.01)$ \\
$31.7 \%$ & $5.7 \%$ & $1.8 \%$ & $5.2 \%$ & $2.3 \%$ & $2.1 \%$ \\
\hline 0.02 & 0.00 & 0.23 & 0.01 & 0.01 & 0.00 \\
0.06 & 0.13 & 0.03 & 0.12 & 0.13 & 0.19 \\
& & $2000.2-2010.12$ & & \\
\hline \multicolumn{7}{c}{} \\
& \multicolumn{7}{c}{} & & &
\end{tabular}


Table VI: Decomposing Bond Risk Premia.

We show statistics for realized and predicted 3-month overlapping log excess returns on real bonds and breakeven, and average log liquidity returns. Realized log excess returns are denoted $x r_{n, t}$, while predicted log excess returns are denoted $E_{t}\left(x r_{n, t+1}\right)$. We report the average log excess return $\hat{E}\left(x r_{n, t}\right)$, stock market beta $\hat{\beta}\left(x r_{n, t}\right)$, standard deviation of predicted log excess returns $\hat{\sigma}\left(E_{t} x r_{n, t+1}\right)$, and the correlation between predicted log excess return and the nominal term spread $\widehat{\operatorname{corr}}\left(E_{t} x r_{n, t+1}, y_{n, t}^{\$}-y_{1, t}^{\$}\right)$. Betas are with respect to excess log stock returns including dividends. We obtain predicted excess returns as fitted values from the regressions shown in Tables $\mathrm{V}(1), \mathrm{V}(3)$ and $\mathrm{V}(5)$. Numbers shown are annualized (\%). Newey-West standard errors for $\hat{\beta}$ are computed with three lags. ${ }^{*}$ and ${ }^{* *}$ denote significance at the $5 \%$ and $1 \%$ level for $\hat{\beta}$, respectively.

Panel A: U.S. (1999.6-2010.12)

$$
\hat{E}\left(x r_{n, t}\right) \quad \hat{\beta}\left(x r_{n, t}\right) \quad \hat{\sigma}\left(E_{t} x r_{n, t+1}\right) \quad \widehat{\operatorname{corr}}\left(E_{t} x r_{n, t+1}, y_{n, t}^{\$}-y_{1, t}^{\$}\right)
$$

\begin{tabular}{lllll}
\hline & & & & \\
Liquidity-Adjusted Breakeven & 0.52 & -0.08 & 1.62 & 0.71 \\
Liquidity-Adjusted Inflation-Indexed & 3.67 & -0.11 & 1.63 & 0.88 \\
Log Return Liquidity & 0.99 & $0.12^{* *}$ & 1.41 & 0.37
\end{tabular}

Panel B: U.K. (2000.2-2010.12)

\begin{tabular}{lcccc} 
& $\hat{E}\left(x r_{n, t}\right)$ & $\hat{\beta}\left(x r_{n, t}\right)$ & $\hat{\sigma}\left(E_{t} x r_{n, t+1}\right)$ & \\
\hline & & & & 0.85 \\
Liquidity-Adjusted Breakeven & -0.34 & $-0.22^{*}$ & 1.93 & 0.90 \\
Liquidity-Adjusted Inflation-Indexed & 0.85 & 0.14 & 2.61 & -0.23 \\
Log Return Liquidity & 1.61 & -0.03 & 2.23 & \\
\hline
\end{tabular}


Panel A: U.S. (1999.3-2010.12)

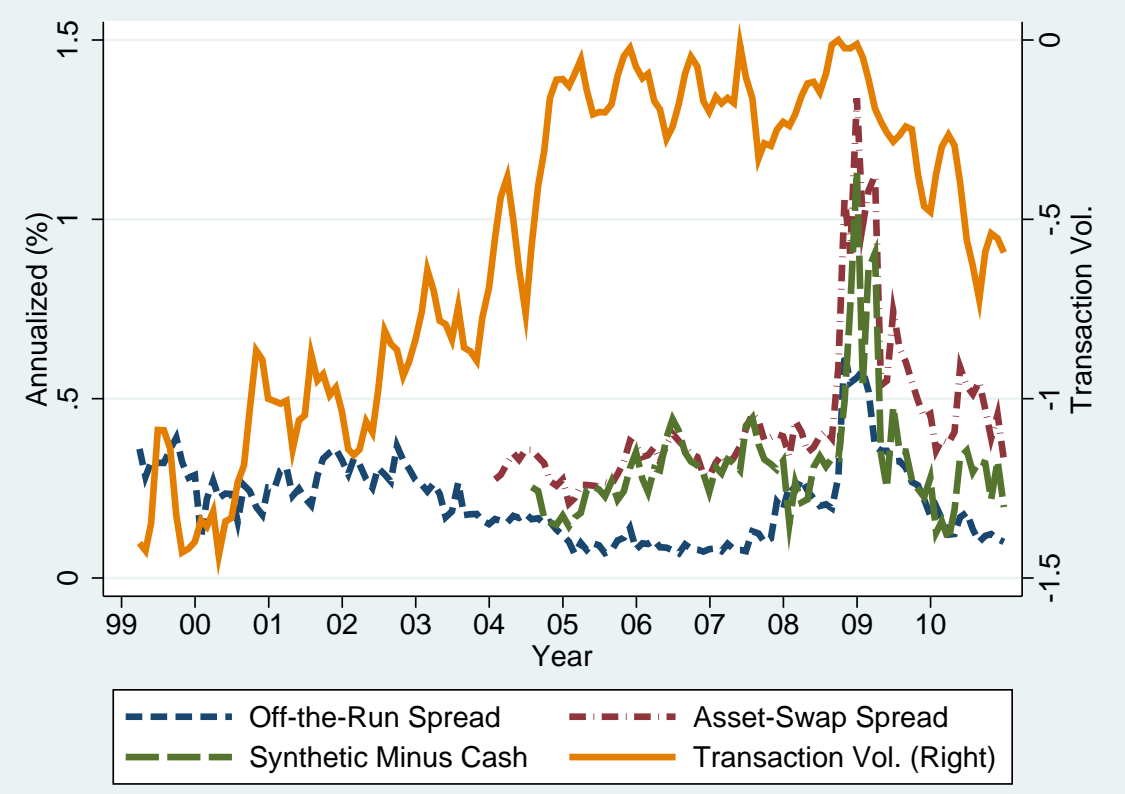

Panel B: U.K. (1999.11-2010.12)

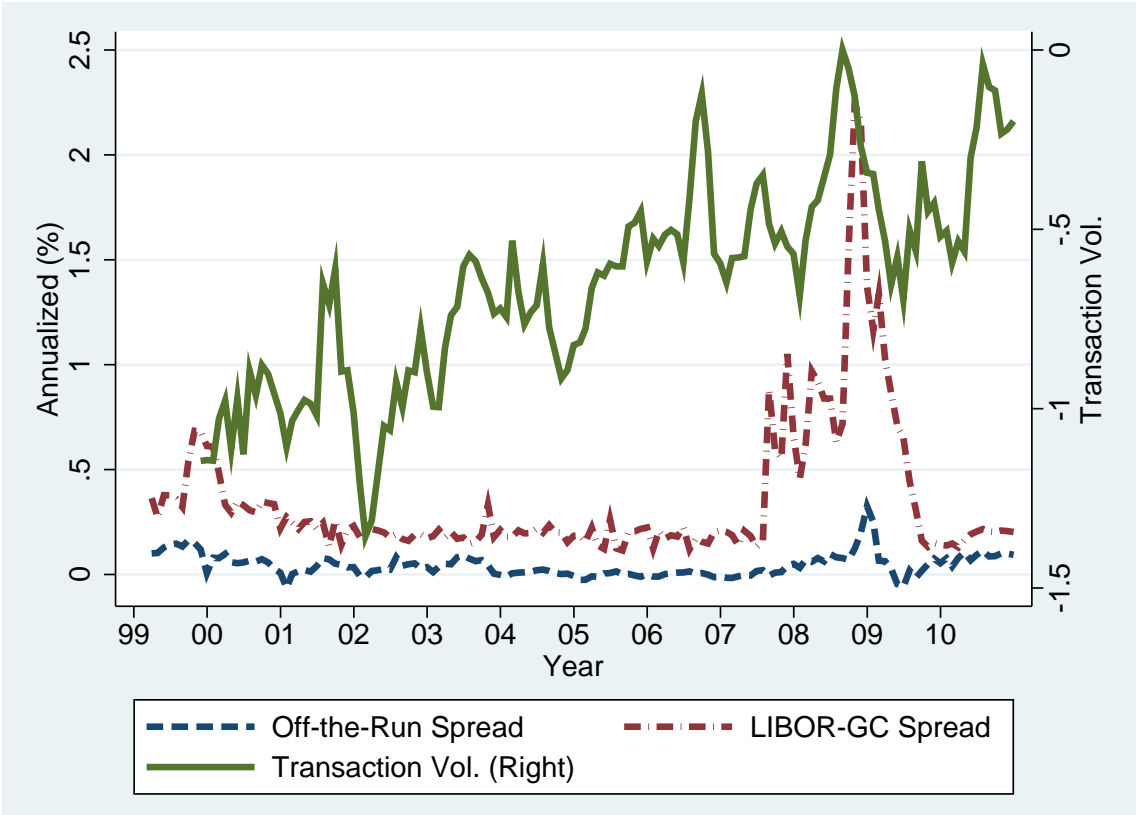

Figure 1: U.S. and U.K. Liquidity Proxies.

We use liquidity proxies to estimate differential liquidity between inflation-indexed and nominal government bonds. For the U.S., we use the spread between off-the-run and on-the-run 10 year nominal bond yields, the relative inflation-indexed bond log transaction volume, the asset-swap differential, and the difference between synthetic and cash breakeven. For the U.K., we use the difference between a 10 year nominal fitted par yield and the 10 year nominal generic Bloomberg yield, denoted "off the run". We normalize the maxima of relative transaction volumes to zero. The asset-swap spread differential, synthetic minus cash breakeven, and the GBP three-month LIBOR-GC spread proxy for the cost of funding a levered investment in inflation-indexed bonds. 
Panel A: U.S. (1999.3-2010.12)

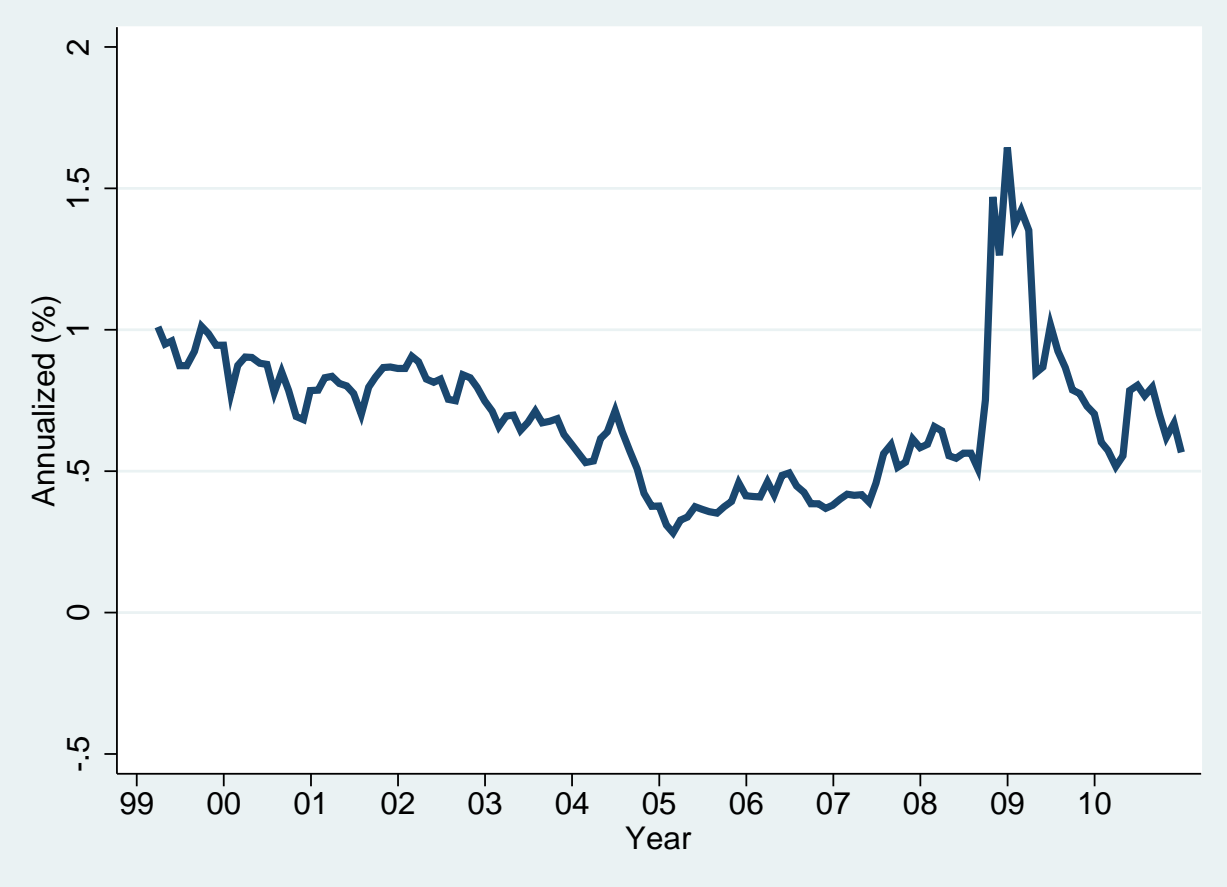

Panel B: U.K. (1999.11-2010.12)

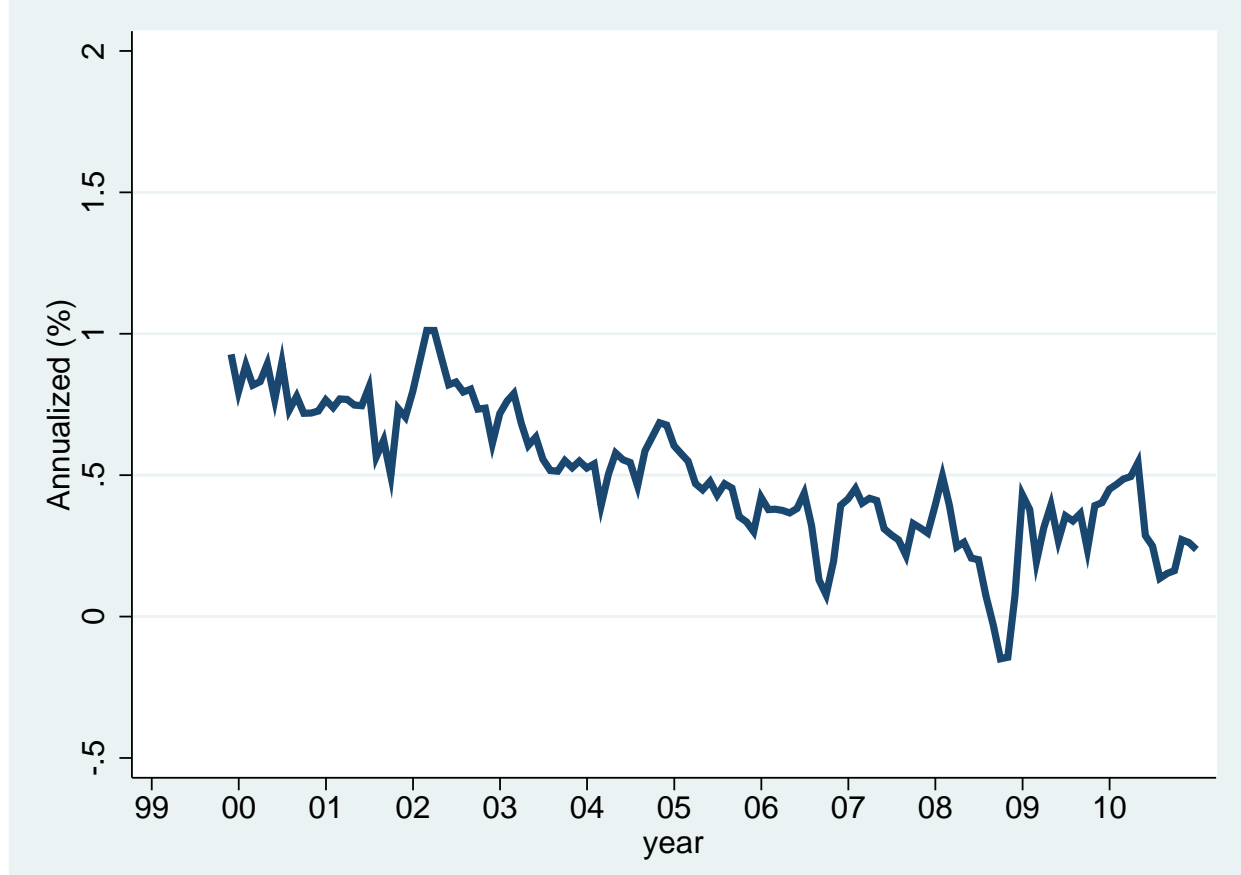

Figure 2: Estimated U.S. and U.K. Liquidity Premia.

We estimate liquidity premia as the negative of the variation in breakeven explained by liquidity proxies. Formally, $\hat{L}_{n, t}=-\hat{a}_{2} X_{t}$, where $X_{t}$ is the vector of liquidity variables and $\hat{a}_{2}$ is the vector of corresponding estimated coefficients in Table II(4), Panels A and B. 
Panel A: U.S. (1999.3-2010.12)

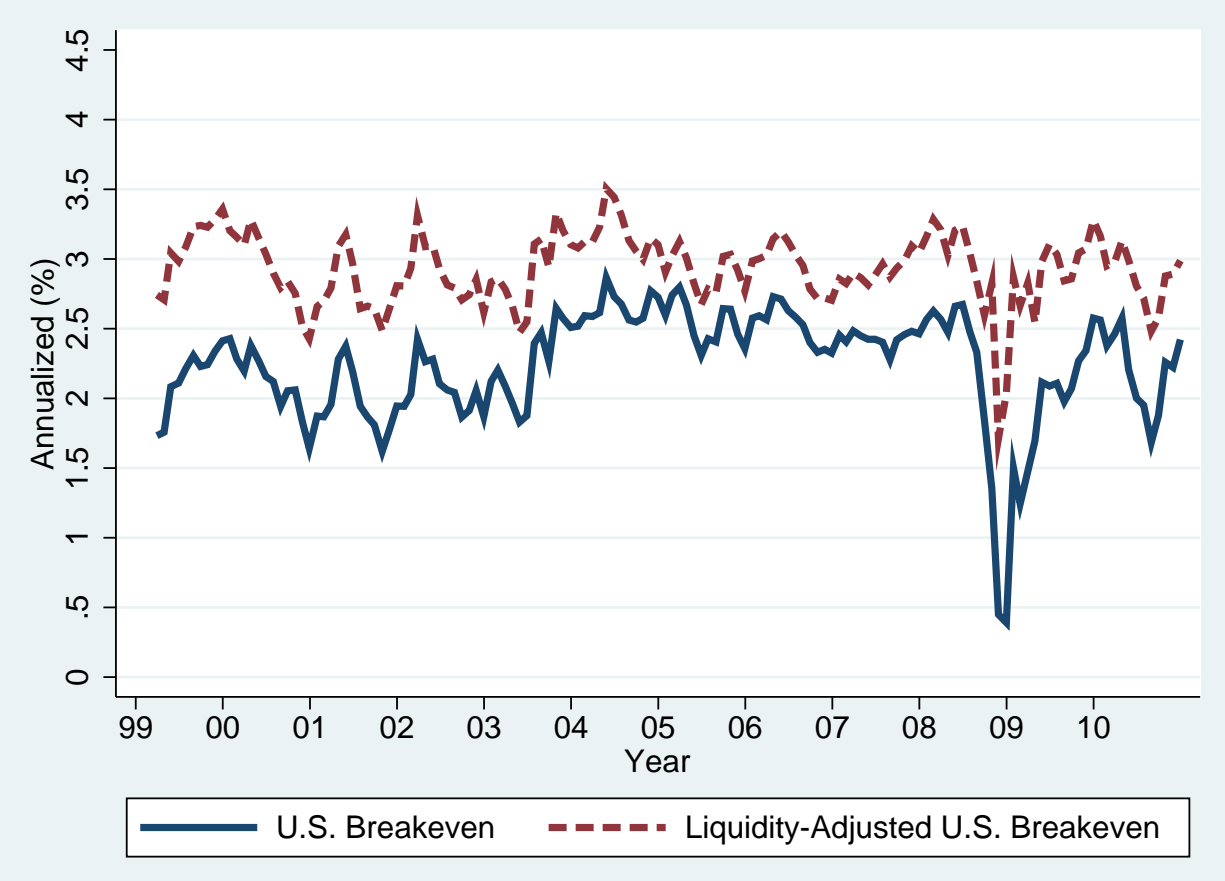

Panel B: U.K. (1999.11-2010.12)

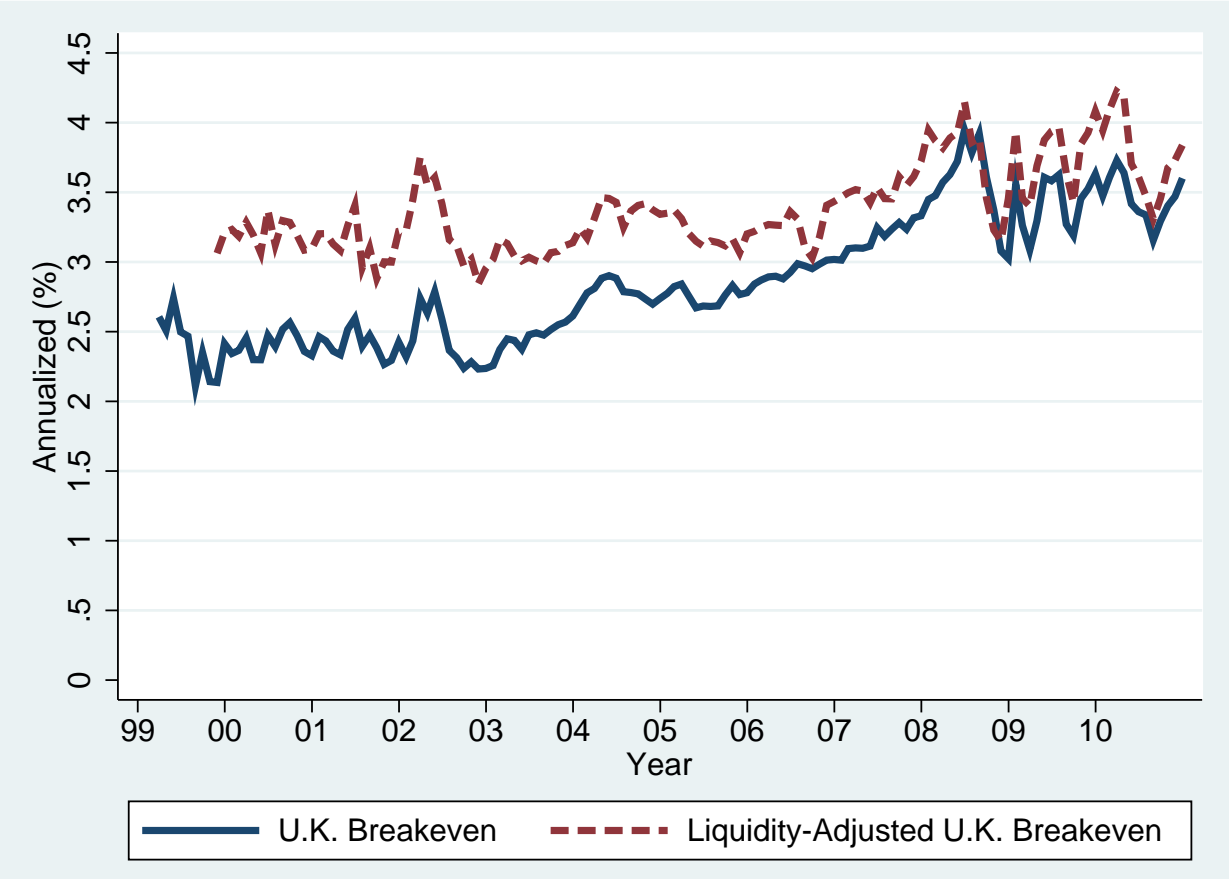

Figure 3: Liquidity-Adjusted U.S. 10 Year Breakeven and U.K. 20 Year Breakeven.

Liquidity-adjusted breakeven equals breakeven plus the liquidity premium shown in Figure 2 . 
Panel A: U.S. (2000.2-2010.12)

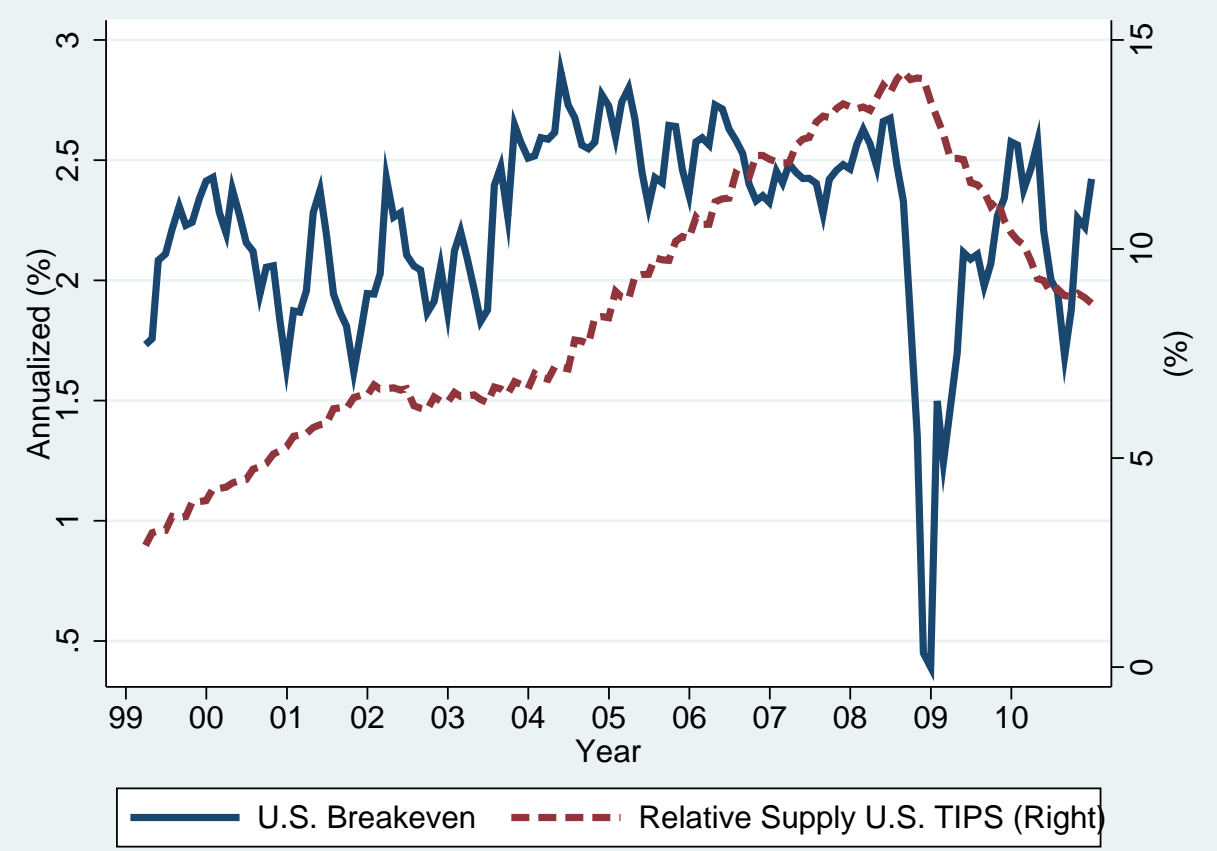

Panel B: U.K. (1986.1-2010.12)

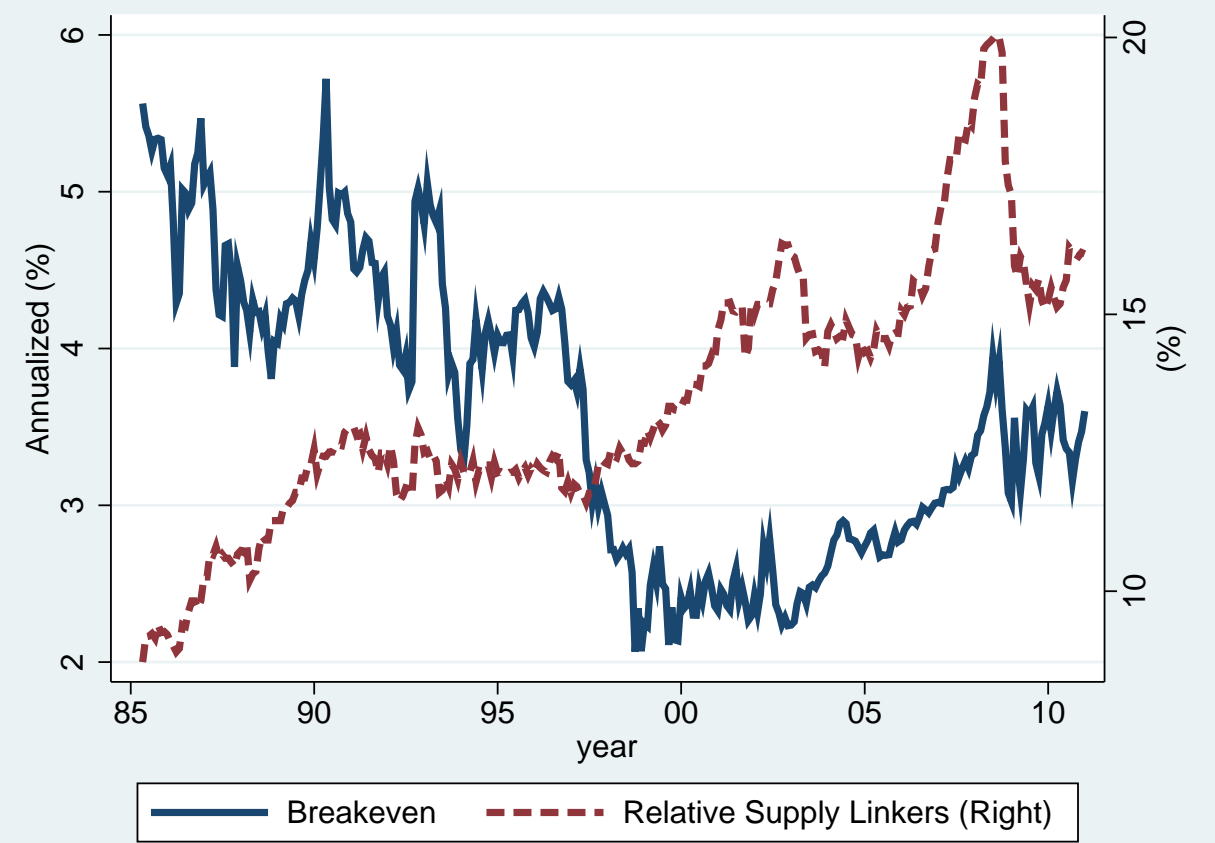

Figure 4: Relative Supply of Inflation-Indexed Bonds and Breakeven.

Relative supply shows the face value of inflation-indexed bonds outstanding relative to the face value of inflation-indexed and nominal bonds outstanding. We show 10 year U.S. breakeven and 20 year U.K. breakeven. 
Panel A: U.S. (1999.6-2010.12)
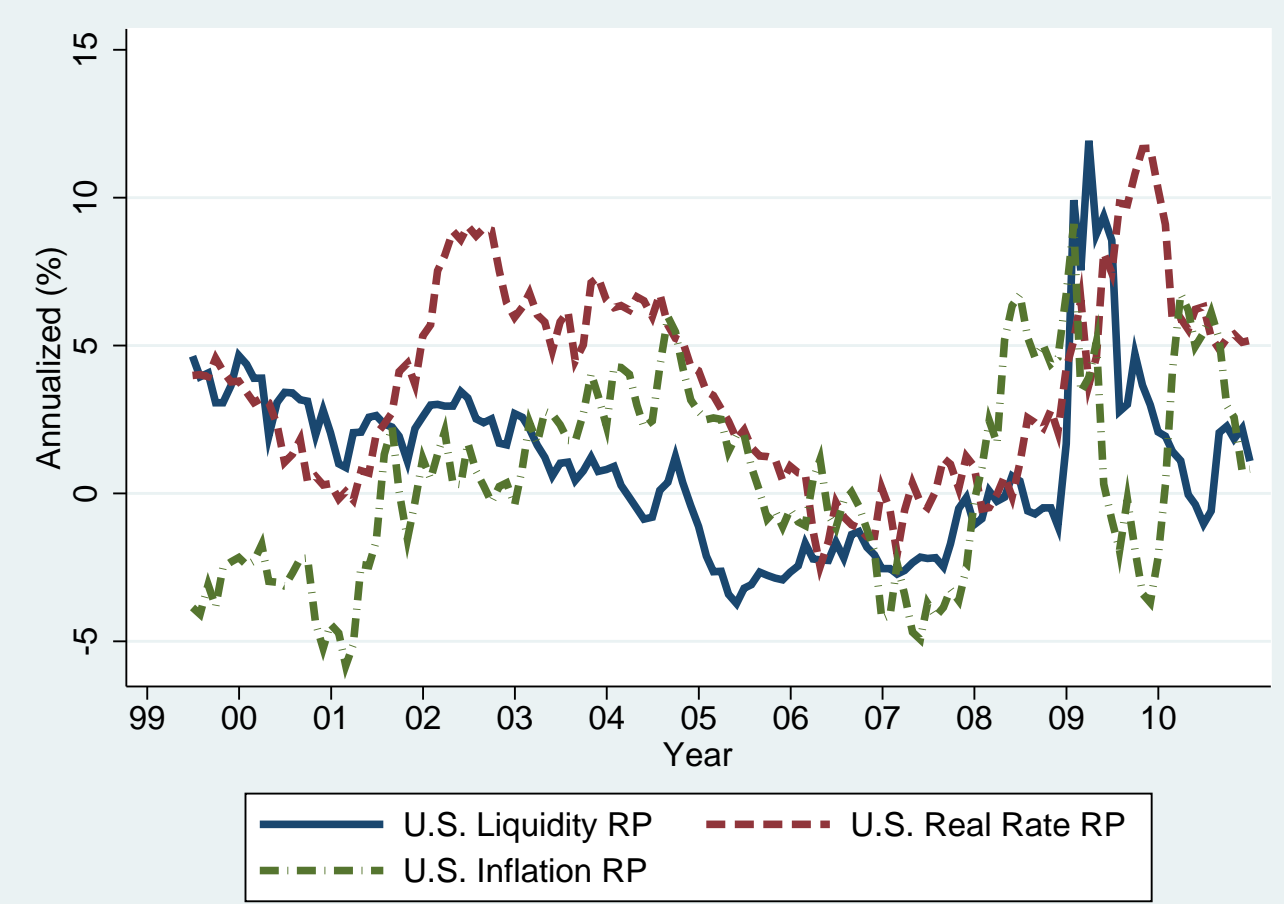

Panel B: U.K. (2000.2-2010.12)

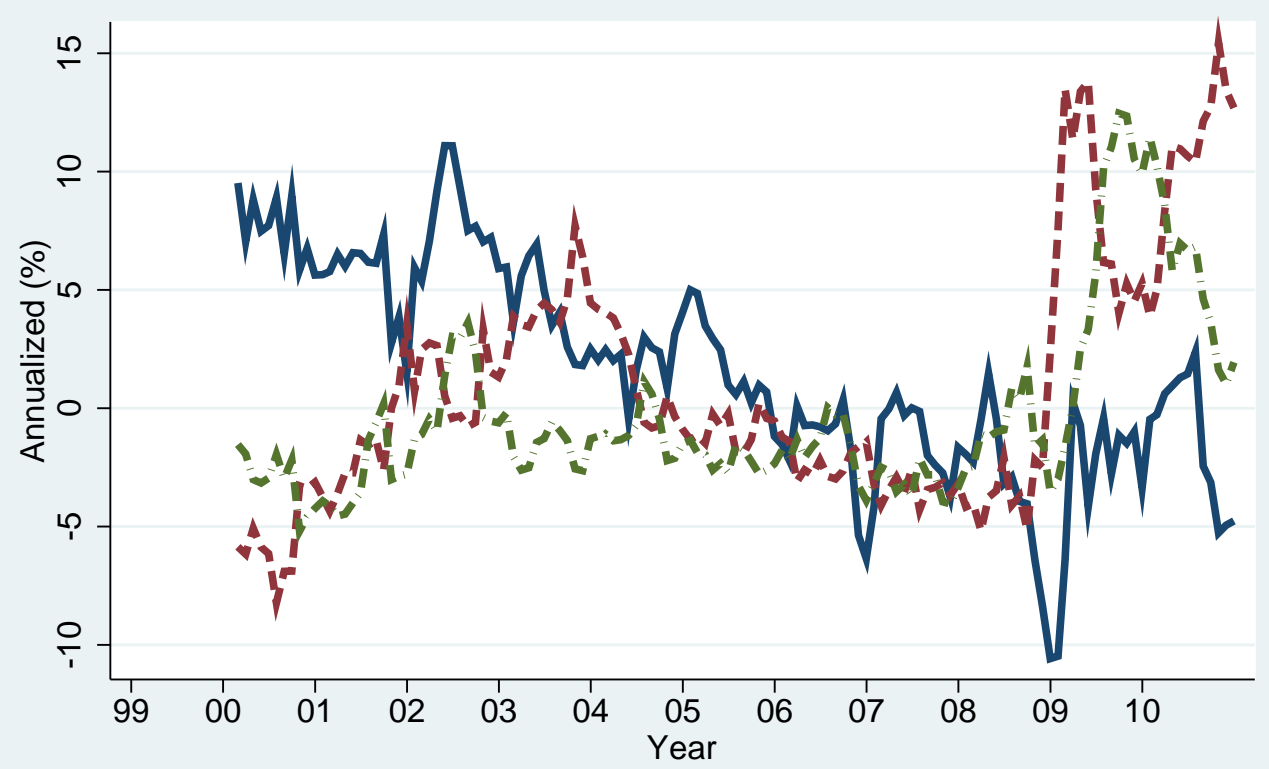

U.K. Liquidity RP $=---=$ U.K. Real Rate RP

U.K. Inflation RP

Figure 5: U.S. and U.K. Estimated Risk Premia.

Predicted 3-month excess returns in annualized units, labeled real rate risk premia, inflation risk premia, and liquidity risk premia. We obtain predicted excess returns as fitted values from the regressions shown in Tables $\mathrm{V}(1), \mathrm{V}(3)$ and $\mathrm{V}(5)$, Panels A and B. 